\title{
How the Knowledge of Interactions between Meningococcus and the Human Immune System Has Been Used to Prepare Effective Neisseria meningitidis Vaccines
}

\author{
R. Gasparini, ${ }^{1}$ D. Panatto, ${ }^{1}$ N. L. Bragazzi, ${ }^{1}$ P. L. Lai, ${ }^{1}$ A. Bechini, ${ }^{2}$ \\ M. Levi, ${ }^{2}$ P. Durando, ${ }^{1}$ and D. Amicizia ${ }^{1}$ \\ ${ }^{1}$ Department of Health Sciences, University of Genoa, Via Pastore 1, 16132 Genoa, Italy \\ ${ }^{2}$ Department of Health Sciences, University of Florence, Viale G.B. Morgagni 48, 50134 Florence, Italy
}

Correspondence should be addressed to R. Gasparini; gasparini@unige.it

Received 21 January 2015; Accepted 9 June 2015

Academic Editor: Nejat K. Egilmez

Copyright (c) 2015 R. Gasparini et al. This is an open access article distributed under the Creative Commons Attribution License, which permits unrestricted use, distribution, and reproduction in any medium, provided the original work is properly cited.

In the last decades, tremendous advancement in dissecting the mechanisms of pathogenicity of Neisseria meningitidis at a molecular level has been achieved, exploiting converging approaches of different disciplines, ranging from pathology to microbiology, immunology, and omics sciences (such as genomics and proteomics). Here, we review the molecular biology of the infectious agent and, in particular, its interactions with the immune system, focusing on both the innate and the adaptive responses. Meningococci exploit different mechanisms and complex machineries in order to subvert the immune system and to avoid being killed. Capsular polysaccharide and lipooligosaccharide glycan composition, in particular, play a major role in circumventing immune response. The understanding of these mechanisms has opened new horizons in the field of vaccinology. Nowadays different licensed meningococcal vaccines are available and used: conjugate meningococcal $\mathrm{C}$ vaccines, tetravalent conjugate vaccines, an affordable conjugate vaccine against the $N$. menigitidis serogroup $\mathrm{A}$, and universal vaccines based on multiple antigens each one with a different and peculiar function against meningococcal group B strains.

\section{Introduction}

The immune system protects humans from attack by microorganisms such as bacteria, viruses, protozoa, fungi, parasites, and organisms such as helminths. The skin is the first barrier and its protective action is enhanced by bodily secretions, such as sweat and sebum, which exert a broad antimicrobial activity $[1,2]$. The mucous membranes are protected by external and internal secretions, such as tears, saliva, and mucus, which contain molecules that can neutralize bacteria. Tissues such as the skin and mucous membranes are populated by immune cells, which can act against the microorganisms that circumvent the first physical and biochemical barriers.

The immune system is very complex and its defensive response is subdivided into innate and adaptive responses [3]. The innate response triggers an immediate, nonspecific, general action and is activated by typical signs of infection.
The adaptive response is able to develop a highly specific, extremely accurate action, which is stored in the so-called immune memory.

This paper provides an overview of the interaction between the immune system and Gram-negative bacteria with particular reference to Neisseria meningitidis in the perspective of developing new vaccines against this pathogen.

\section{Gram-Negative Bacteria and Immunity}

2.1. Outer Membrane Components. Over thousands of years, bacteria have developed several mechanisms whereby they can circumvent the immune system. Specifically, Gramnegative bacteria possess a complex of envelopes, which allow the selective passage of nutrients into the cell and the excretion of metabolic waste outside. Structurally, Gramnegative bacteria possess an outer membrane $(\mathrm{OM})$, which, 
together with the peptidoglycan and inner membrane (IM), delimits the periplasm and cytoplasm compartments. Many molecules of glycolipids, especially lipopolysaccharide (LPS), emerge from the outer leaflet of the OM, while, from the inner layer of the OM, lipoproteins reach the peptidoglycan, with which they engage. Moreover, proteins such as porins cross the OM; these are very important for the active, passive, and selective permeability of small molecules, ions, and water [4]. Most porins have a trimeric structure and an oval shape. The bacterial porins perform many functions; indeed, they help the microorganism to adhere to the cells of the host tissue and to evade the defence mechanisms of the human body, thereby favouring invasion of the host. They are also able to elicit both innate and adaptive immunity. Porins can inhibit phagocytic activity [5] and activate the complement system by means of both classic and alternative pathways [6]. For instance, Neisserial porins can activate the transport of NF- $\kappa \mathrm{B}$ into the nucleus of B and dendritic cells (DCs) [7]. The DNA/NF$\kappa \mathrm{B}$ complex then recalls other proteins, such as coactivators and RNA polymerase, which transcribe the DNA into mRNA; finally, this mRNA is exported to the cytosol and translated into proteins. This leads to a change in the function of the cell; for example, the cell may begin to produce proinflammatory cytokines.

Porins are clearly involved in the induction of proinflammatory activity, although it is not known which tolllike receptors recognize them. By contrast, it is known that LPS stimulates toll-like receptors 2 and 4 [8]. Three distinct regions characterize LPS, namely, lipid A, which fixes the molecule to the outer leaflet of the OM, the core polysaccharide which binds to lipid A by means of a disaccharide phosphate bridge, and antigen $\mathrm{O}$, which is the most distal portion. The general structure of LPS is fully conserved, while the core oligosaccharide is highly variable.

Toll-like receptors are a family of conserved signal transducers able to induce an innate immune response. To date, at least 11 mammalian TLRs have been identified. Their stimulation by bacterial components activates the innate immune response. TLR2 recognizes peptidoglycan, lipopeptides, and bacterial proteins. However, it is interesting that LPS can overstimulate the innate immune response, thereby eliciting inflammation. As a result, the normal defences may not function correctly. Furthermore, it should be borne in mind that TLR5 recognizes flagellin, which is the main component of bacterial flagella [9]. For example, mutations of the TLR4 gene contribute to development of severe meningococcal infections [10]. In addition, through the recognition of $N$. meningitidis DNA, TLR9 exerts strong protection against the microorganism [11].

2.2. Innate and Adaptive Immune Responses. The innate immune system is able to detect other conserved microbial components, called pathogen-associated molecular patterns (PAMPs), such as nucleic acid structures, lipoteichoic acid, and peptidoglycan [12]. The pattern recognition receptors (PRRs) of immune cells include, in addition to TLRs, the NOD-like receptors (NLRs) and the RIG-1-like receptors (RLRs), which are able to recognize microbial components in the cytosol [13]. TLRs, NLRs, and RLRs are able to activate mitogen-activated protein kinase (MAPK) and the transcription of NF- $\kappa$ B factor. A different set of NLRs helps to activate caspase- 1 and the consequent assembly of inflammasomes [14].

The granulocytes and macrophages are the first cells that participate in the activation of the innate immune response. Shortly afterwards, the DCs and natural killer cells are activated. Specifically, neutrophils produce antimicrobial proteins, such as LL37, alpha and beta defensins, enzymes [15], interferons (IFN) alpha, beta, and gamma, Creactive protein, and chemokines, contribute to activating the complement cascade. Macrophages produce reactive oxygen species (ROS) (e.g., $\mathrm{H}_{2} \mathrm{O}_{2}$ ) and reactive nitrogen species (RNS). Subsequently, DCs, which can also be activated by TLR2 and TLR4, activate natural killer (NKs) cells [16] and induce maturation of CD4+ T cells [17-22].

Many bacterial components are able to stimulate the adaptive human immune response. Porins can activate the translation of NF- $\kappa \mathrm{B}$ in the nucleus of $\mathrm{B}$ and DCs, while class I Pilin E induces highly specific antibodies (Abs) and class II induces cross-reacting Abs. Furthermore, complement cascade activation, as well as particularly C3b activation, opsonizes antigens, thereby enabling APCs to activate the adaptive response.

\section{Neisseria meningitidis and Immunity}

3.1. Meningococcal Genome. Meningococci have developed several "immunoescape" strategies [23], the molecular bases of which can be understood by taking into account the nature of the Neisserial genome. Progress in the field of molecular biology and the introduction of high-throughput technologies (HTTs) have tremendously advanced our understanding of the complexity of the Neisserial machinery. By using sophisticated approaches such as whole-genome sequencing (WGS) and microarrays, functional genomics investigations have uncovered the mechanisms that facilitate or hinder $N$. meningitidis growth, colonization, and invasion and have helped to explain its extraordinary intrastrain variation and adaptation to the environment. Other techniques, such as genome-wide association studies (GWAS), have shed light on the pathogen-host interaction and the host's susceptibility to the microbe. Genomics and postgenomics have not only increased our knowledge of the biology and pathogenesis of $N$. meningitidis but proved to be extremely useful in discovering candidate antigens and in developing effective new vaccines [24].

Being a naturally competent pathogen, $N$. meningitidis has a highly dynamic, plastic, and flexible genome with a size range of only more than 2,000 kilobases [25]. This genome differs from other microbial genomes in that it lacks some of the typical two-component systems and sigma factors [26]. Despite being relatively small and compact, it has elaborated a variety of mechanisms that contribute to explaining its high adaptability both to host and to environment. Meningococcus is usually polyploid, containing up to 2-5 genomespolyploidy being a sign of virulence-while $N$. lactamica is monoploid [27]. Neisserial pathogenicity is intrinsically polygenic [28] and is given by a variety of different pathogenic 
islands (PAIs or genomic islands, GEIs), including gonococcal genetic islands (GGIs) [29] and a recently discovered meningococcal disease-associated (MDA) island [30].

The nature of the Neisserial chromosome and the presence of extrachromosomal material contribute to explaining an important immunoescape strategy, known as structural or antigenic variation, which consists of camouflage of the Neisserial repertoire expressed. Basically, it can involve horizontal or lateral gene transfer (HGT/LGT) (mainly via transformation and, to a lesser extent, via conjugation and phage transduction) and allelic exchange/rearrangement of genes or gene portions taken up from the environment (Table 1). In addition, as its genome contains multiple copies of certain genes, for example, opacity factor proteins and pilins [31], homologous intragenic recombination also results in frequent surface structural variation.

Moreover, the pathogen hosts a number of prophages, from the Mu-related family to the phage l-related group and the family of filamentous M13-like phages [27, 32]. The most widely studied sites for phage integration are known as duplicated repeat sequence 3 (dRS3) [26], which belong to the family of Neisserial intergenic mosaic elements (NIMEs). Plasmids, such as pJS-A and PJS-B, also play an important role [33].

Another surface modulation occurs via phase variation, a process involving the modulation of gene expression via a mechanism of on/off switching (transition from an expressed state of the gene to an unexpressed one or vice versa). Besides this kind of "functional" phase variation, Neisseria can also undergo a "structural" switch, namely, a transition between two forms of a gene product. The genes, which are involved in this strategy, are termed "contingency genes" [26] and can be coupled and interlinked in structures called phasevarions (phase-variable regulons) [34], which have a regulatory function. Phase variation includes a variety of sophisticated mechanisms [35], such as slipped strand mispairing (SSM) [36], microsatellite instability [37], and reversible insertion of minimal mobile elements (MMEs) [38]. Therefore, these mechanisms can involve single nucleotides (homopolymeric repeats) or complex nucleotidic structures (short tandem repeats), occurring either upstream of a gene in the promoter or within an open reading frame (ORF)/coding sequence (CDS). Changes upstream of a gene result in modulation of its transcriptional efficiency and therefore of its final protein concentration. This is, for example, the case of Opc, porin $\mathrm{A}$ (porA), and fet $\mathrm{A}$ genes. Alterations within a gene, which insert de novo stop codons, alter the full translation of the gene. An example of this mechanism is provided by the opa genes and the genes coding for adhesins, such as nadA [39]. Phase variation of opa genes has been extensively characterized: they occur in four distinct copies and code for similar, but not identical, proteins. Phase variation can thus involve one copy or another, independently of each other, and can result in eleven variants. In this case, phase variation is therefore equivalent to antigenic variation. Besides opacity factor proteins, phase variation can involve up to hundreds of genes [40]: from the genes coding for pilins [41] or for proteins involved in genome maintenance and DNA repair $[42,43]$ to genes encoding proteins involved in the cell cycle control and regulation [44], autotransporters [45, 46], or enzymes like the pilin phosphorylcholine transferase $p p t \mathrm{~A}$ [47] or the glycosylase $m u t Y$ [48], among others [49, 50]; the reader is referred to Table 2 , which provides a more detailed overview of the phase-variable genes. Moreover, new mechanisms leading to phase variations have been discovered [51].

The mechanism implying MMEs involves different kinds of genetic elements, such as the Correia repeats (CRs) and the Correia repeat-enclosed elements (CREEs), known also as the Neisseria miniature insertion sequences (NEMIS) [52, 53], which constitute about $2 \%$ of the Neisserial genome [54]. Other genetic elements are the insertion sequence (IS) elements, such as IS1016-like, IS1106, IS1301 [55, 56], and IS1655 [57].

It is worth noting that the number of genes involved in phase variation is enormously greater than for any other pathogen studies so far [58]. Some genes are "phasotypes"; that is to say, they play a role in carriage and are downregulated, favouring host persistence [59].

As already mentioned, in some cases antigenic/structural variation and phase variation, albeit conceptually two distinct mechanisms, cooperate in increasing the genetic complexity of the Neisserial genome. Antigenic variation of LPS, for example, can derive from phase variation of one or more enzymes involved in the synthesis of the oligosaccharide chain by SSM, or by modification of LPS, for example, by glycosylation [60-62], sialylation [63, 64], or acetylation $[65,66]$, which, moreover, confer resistance to neutrophilmediated killing.

Thus, both antigenic and phase variations concur in enabling Neisseria to evade the immune system [26, 27].

3.2. Meningococcal Capsule. LPS and themeningococcal capsule (CP) are the two major virulence factors of $N$. meningitidis. Specifically, the capsule displays a large variability of surface antigens, on the basis of which 13 different N. meningitidis serogroups have been identified. The $\mathrm{CP}$ contributes in an important way to the camouflage of the microorganism, which thus can better circumvent the immune system's defences. The clearest expression of this phenomenon is given by the molecular mimicry [67]. This can be seen in the nature of the polysaccharide $\mathrm{CP}$ of serogroup $\mathrm{B}$ meningococcus, a homopolymer of $\alpha 2-8$-linked sialic acid, which is identical to a neural cell adhesion molecule, NCAM-1 [68]. Moreover, lacto-N-neotetraose (L-NNT) in the lipopolysaccharide of virulent strains is similar to an antigen expressed on red blood cells [69-73]. Further mechanisms of molecular mimicry have been recently discovered and described [74].

During the first phase of infection, meningococcus has to avoid the surface defences of the nasopharynx, such as the peptides secreted at the mucosal surface [90] and IgA secretory Abs $[90,196]$. To this end, the meningococcus can aggregate into clusters and produce abundant $\mathrm{OM}$ vesicles (OMVs), thus managing to hide its surface antigens and to deflect the action of the surface defences from the bacterial cell [196]. In addition, the CP protects Neisseria from 
TABLE 1: An overview of the most important immunoescape strategies exploited by Neisseria meningitidis.

\begin{tabular}{|c|c|c|}
\hline $\begin{array}{l}\text { Immunoescape } \\
\text { mechanism }\end{array}$ & Details & References \\
\hline $\begin{array}{l}\text { Structural/antigenic } \\
\text { variation }\end{array}$ & $\begin{array}{l}\text { It consists in the modified expression of domains, which are antigenically different within a clonal } \\
\text { population, by which the pathogen is able to escape the host immunity selection and circumvent } \\
\text { the immune surveillance } \\
\text { It usually involves LOS/LPS, opacity, and pilin proteins } \\
\text { LOS/LPS and opacity factor structural/antigenic variation depends essentially on phase variation } \\
\text { Pili antigenic variations depend on RecA-mediated recombination }\end{array}$ & {$[31,75,76]$} \\
\hline Autolysis & It is mediated by OMPLA & [77] \\
\hline $\begin{array}{l}\text { Blebbing and } \\
\text { microvesicles formation }\end{array}$ & The blebs originate as evaginations of the outer layer & [78] \\
\hline Capsule switching & $\begin{array}{l}\text { Due to microevolution, there is shift from serogroup B to serogroup C, from serogroup C to } \\
\text { W-135, from serogroup Y to W-135, and from serogroup Y to B; nanostructured materials such as } \\
\text { MWNTs and mesoporous silica increase transformational capacity }\end{array}$ & {$[30,79-87]$} \\
\hline Capsule modification & $\begin{array}{l}\text { For example, modification of lipid A of meningococcal LOS/LPS with phosphoethanolamine } \\
\text { protects Neisseria from neutrophils-mediated killing } \\
\text { Another example is given by the O-acetylation of capsular antigens (LpxL2 gene mutants are } \\
\text { indeed more virulent) } \\
\text { LpxL1 gene mutants activate TLR4 less efficiently }\end{array}$ & {$[88]$} \\
\hline Genome plasticity & $\begin{array}{l}\text { HGT/LGT (via conjugation, transduction, and transformation) and homologous intragenic } \\
\text { recombination }\end{array}$ & $\begin{array}{l}{[25,27,30,} \\
89]\end{array}$ \\
\hline Host modification & $\begin{array}{l}\text { Neisseria exploits a bacterial sialyltransferase scavenging available host CMP-NANA for } \\
\text { modifying LOS/LPS }\end{array}$ & {$[70]$} \\
\hline Molecular mimicry & $\begin{array}{l}\text { CP of serogroup B strain is a homopolymer of } \alpha 2-8 \text {-linked sialic acid and is similar to NCAM-1 } \\
\text { L-NNT in the lipopolysaccharide of virulent strains is similar to an antigen on red blood cells } \\
\text { DMP19 acts as a DNA-mimic protein }\end{array}$ & $\begin{array}{l}{[67,69,71-} \\
74,90,91]\end{array}$ \\
\hline Metabolic pathways & $\begin{array}{l}\text { Examples are iron, lactate, glutamate uptake, utilization, and avoidance of neutrophil oxidation } \\
\text { burst, ROS, and RNS }\end{array}$ & {$[92,93]$} \\
\hline Molecular decoy & $\begin{array}{l}\text { FprB has an antigenic subdomain for binding antibodies, which is not essential for the } \\
\text { functioning of the autotransporter; it also blebs with OMPs and LPS/LOS distract the immune } \\
\text { system, directing the response away from the microbe }\end{array}$ & {$[94]$} \\
\hline Immunotype switch & $\begin{array}{l}\text { LPS immunotype switches from L } 3 \text { to } \mathrm{L} 8 / \mathrm{L} 1 \text { by lgtA, lgtC phase variation } \\
\text { LOS immunotype can contribute to immunoescape }\end{array}$ & {$[95,96]$} \\
\hline Phages and prophages & $\begin{array}{l}\text { The pathogen hosts a number of prophages, from the Mu-related family to the phage l-related } \\
\text { group and the family of filamentous M13-like phages }\end{array}$ & {$[25,30,89]$} \\
\hline Phase variation & $\begin{array}{l}\text { High-frequency reversible changes can occur in the length of SSRs (of capsule, LOS, opacity } \\
\text { factor, porin, adhesin, invasin, autotransporter, haemoglobin receptor, DNA mismatch repair, and } \\
\text { pilin genes, termed as contingency genes and organized in modules called phasevarions) } \\
\text { Other repeat sequences can be REP2, CRs, CREEs, and NIMEs } \\
\text { Transposon-like elements can play a role } \\
\text { Phase variation mediates resistance to antibiotics } \\
\text { Phase variation mediates carriage persistence }\end{array}$ & {$[50,52,59]$} \\
\hline $\begin{array}{l}\text { Pilin conversion and } \\
\text { modification }\end{array}$ & $\begin{array}{l}\text { Pilin is posttranslationally modified by addition of a glycan, two phosphorylcholines, and a } \\
\text { glyceramido acetamido trideoxyhexose residue }\end{array}$ & {$[97,98]$} \\
\hline Plasmid & Examples of plasmids that can contribute to Neisseria variability are pJS-A, pJS-B & [33] \\
\hline $\begin{array}{l}\text { Recruitment of human } \\
\text { components of immune } \\
\text { system }\end{array}$ & Neisseria escapes complement-mediated killing recruiting and sequestering $\mathrm{fH}$ to its surface & {$[91]$} \\
\hline $\begin{array}{l}\text { Temperature-regulated } \\
\text { defence }\end{array}$ & $\begin{array}{l}\text { RNA thermosensors finely tune the expression of CP components, LOS, and fHBP, thus } \\
\text { protecting against human immune killing }\end{array}$ & [99] \\
\hline \multicolumn{3}{|c|}{$\begin{array}{l}\text { CMP-NANA: cytidine } 5^{\prime} \text {-monophospho-N-acetylneuraminic acid; CP: capsule; CRs: Correia repeats; CREE: Correia repeat-enclosed element; DNA: } \\
\text { deoxyribonucleic acid; fH: complement factor H; fHBP: fH binding protein; HGT: horizontal gene transfer; lgt: prolipoprotein diacylglyceryl transferase; L- } \\
\text { NNT: lacto-N-neotetraose; LOS: lipooligosaccharide; LPS: lipopolysaccharide; LGT: lateral gene transfer; MWNTs: multiwalled nanotubes; NCAM-1: neural } \\
\text { cell adhesion molecule 1; NIME: Neisserial intergenic mosaic element; OMPs: outer membrane proteins; OMPLA: outer membrane phospholipase A; RecA: } \\
\text { recombinase A; REP2: repetitive extragenic palindromic sequence; RNA: ribonucleic acid; RNS: reactive nitrogen species; ROS: reactive oxygen species; SSRs: } \\
\text { simple sequence repeats; TLR: toll-like receptor. }\end{array}$} \\
\hline
\end{tabular}


TABLE 2: An overview of the most important genes and gene products of Neisseria meningitidis involved in immunoescape mechanisms.

\begin{tabular}{|c|c|c|}
\hline N. meningitidis molecule & Immunological role & Reference \\
\hline $\operatorname{aniA}$ & $\begin{array}{l}\text { A nitrite reductase: it protects Neisseria from nitrosative stress } \\
\text { during both colonization and invasion }\end{array}$ & $\begin{array}{l}{[90,100-} \\
102]\end{array}$ \\
\hline App & It is phase-variable & [103] \\
\hline ausI/MspA & An autotransporter and a serine protease; it is phase-variable & {$[45,46]$} \\
\hline $\begin{array}{l}\text { Biofilm (and molecules involved in the biofilm } \\
\text { synthesis, such as autA or } h r p A \text {, or optimizing } \\
\text { pathogen survival in biofilm, such as the alpha-peptide } \\
\text { of IgA1 protease, adhC, estD) }\end{array}$ & $\begin{array}{l}\text { Biofilm protects from macrophages; adhC is involved in } \\
\text { S-nitrosoglutathione metabolism and in glutathione-dependent } \\
\text { detoxification system; EstD is involved also in Neisseria } \\
\text { colonization }\end{array}$ & {$[104-108]$} \\
\hline Blebs (with OMPs and LPS/LOS) and SOMVs & $\begin{array}{l}\text { They protect from neutrophils-mediated killing and NETs; they } \\
\text { divert the immune response away from the pathogen }\end{array}$ & {$[78]$} \\
\hline $\begin{array}{l}\text { Capsule and molecules involved in the capsule } \\
\text { synthesis such as } k p s C, k p s S\end{array}$ & $\begin{array}{l}\text { It activates TLR2 pathway, it increases serum resistance, and it } \\
\text { inhibits the classical pathway of complement }\end{array}$ & [109-111] \\
\hline Cas9 and the CRISPR-Cas system & $\begin{array}{l}\text { CRISPR-Cas9-mediated repression of bacterial lipoprotein } \\
\text { expression facilitates evasion of TLR2 by the pathogen; it is } \\
\text { involved in gene expression and regulation }\end{array}$ & {$[112,113]$} \\
\hline $\operatorname{cbp} \mathrm{A}$ & It mediates zinc piracy and protects from nutritional immunity & [93] \\
\hline Cps & $\begin{array}{l}\text { As a gene, it is involved in the capsule biosynthesis; as RNA, it acts } \\
\text { as a thermosensor; Cps gene amplification protects the pathogen }\end{array}$ & {$[99,114]$} \\
\hline $\operatorname{Crg} A$ & $\begin{array}{l}\text { It is involved in the regulation of pili and capsule expression; it } \\
\text { plays a major role in the infectious cycle of Neisseria }\end{array}$ & {$[114-116]$} \\
\hline Css & $\begin{array}{l}\text { As a gene, it is involved in the capsule biosynthesis; as RNA, it acts } \\
\text { as a thermosensor }\end{array}$ & {$[99]$} \\
\hline$c t r \mathrm{~A}, c t r \mathrm{D}$ & $\begin{array}{l}\text { As genes, they are involved in the capsule export; as RNAs, they act } \\
\text { as thermosensors; IS1301 in the IGR between sia and ctr operons } \\
\text { mediates resistance to Abs }\end{array}$ & {$[99,117,118]$} \\
\hline$c y c \mathrm{P}$ & $\begin{array}{l}\text { It is involved in denitrification metabolism and protects Neisseria } \\
\text { from nitrosative stress }\end{array}$ & {$[90,119,120]$} \\
\hline dam & It is involved in phase variation and modulation & {$[42]$} \\
\hline$d c a \mathrm{C}$ & It is phase-variable & {$[40]$} \\
\hline $\operatorname{din} \mathrm{B}$ & $\begin{array}{l}\text { A DNA polymerase IV belonging to the SOS regulon: it is involved } \\
\text { in phase variation and modulation }\end{array}$ & {$[42]$} \\
\hline $\begin{array}{l}\text { DNA mismatch repair genes }(f p g, m u t \mathrm{~L}, m u t \mathrm{~S}, m u t \mathrm{Y}, \\
r e c \mathrm{~A}, r e c \mathrm{~N}, u v r \mathrm{D})\end{array}$ & They are phase-variables; they protect against oxidative stress & $\begin{array}{l}{[42,48,51,} \\
121]\end{array}$ \\
\hline $\operatorname{drg}$ & It is involved in phase variation and modulation & {$[42]$} \\
\hline far $\mathrm{A}$, far $\mathrm{B}$, far $\mathrm{R}$ & $\begin{array}{l}\text { They remove antimicrobial peptides, proteases, lysozyme, and } \\
\text { acids from the bacterial cytosol and protect the pathogen }\end{array}$ & {$[122,123]$} \\
\hline$f b p \mathrm{~A}, f b p \mathrm{~B}$ & They are involved in phase variation and modulation & {$[51]$} \\
\hline Feta & It is involved in phase variation and modulation & {$[124-126]$} \\
\hline fHbp (formerly known as GNA1870) & $\begin{array}{l}\text { It is involved in phase variation and modulation; it protects } \\
\text { Neisseria from complement-mediated killing, binding fH }\end{array}$ & {$[90,127]$} \\
\hline$f r p \mathrm{~A}, f r p \mathrm{~B}, f r p \mathrm{C}$ & They are phase-variable; they can act as a molecular decoy & $\begin{array}{l}{[124,125,} \\
128]\end{array}$ \\
\hline funZ & It is a site of bacteriophage insertion; it is phase-variable & {$[49]$} \\
\hline fur & $\begin{array}{l}\text { It is involved in phase variation and modulation; it tunes the gene } \\
\text { expression of virulence genes }\end{array}$ & {$[102,129]$} \\
\hline$g g t$ & It regulates pathogen growth & {$[130]$} \\
\hline Ght & $\begin{array}{l}\text { It is involved in the capsule biosynthesis and in the resistance } \\
\text { mechanisms of the pathogen }\end{array}$ & {$[131,132]$} \\
\hline$g l t \mathrm{~T}$ & $\begin{array}{l}\text { It favours meningococcal internalization into human endothelial } \\
\text { and epithelial cells; it regulates pathogen growth }\end{array}$ & {$[133,134]$} \\
\hline H.8 & AAEAP motifs are target for generation of blocking Abs & {$[135-138]$} \\
\hline
\end{tabular}


TABLE 2: Continued.

\begin{tabular}{|c|c|c|}
\hline N. meningitidis molecule & Immunological role & Reference \\
\hline $\begin{array}{l}\text { Haemoglobin-linked iron receptors ( } h p u A, h p u B \text {, } \\
h m b R)\end{array}$ & They are involved in phase variation and modulation & {$[43,139-141]$} \\
\hline 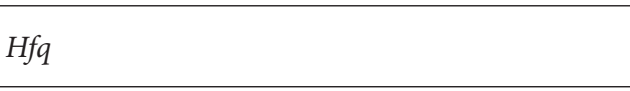 & $\begin{array}{l}\text { A RNA chaperone: it is involved in stress response and virulence } \\
\text { and is a pleiotropic regulator of protein expression }\end{array}$ & {$[142]$} \\
\hline$h s d \mathrm{~S}$ & It is phase-variable & {$[49]$} \\
\hline IgA protease & $\begin{array}{l}\text { It cleaves secretory } \operatorname{IgA} \text {, hinders Ab binding and function, and may } \\
\text { play role in biofilm formation; it cleaves lysosomal LAMP1 in } \\
\text { epithelial cells; moreover, it is phase-variable }\end{array}$ & $\begin{array}{l}{[122,142,} \\
143]\end{array}$ \\
\hline katA & $\begin{array}{l}\text { It confers resistance to RNS, including peroxynitrite (PN), protects } \\
\text { against ROS, and detoxifies } \mathrm{H}_{2} \mathrm{O}_{2}\end{array}$ & $\begin{array}{l}{[90,102,122,} \\
144]\end{array}$ \\
\hline Laz & $\begin{array}{l}\text { A lipid-modified azurin: it protects against hydrogen peroxide and } \\
\text { copper toxicity; it promotes Neisseria growth and survival }\end{array}$ & $\begin{array}{c}{[135,138} \\
145]\end{array}$ \\
\hline$l b p A, l b p B$ & $\begin{array}{l}\text { They are involved in iron acquisition and metabolism; they are } \\
\text { phase-variable; moreover, the release of LbpB enables Neisseria to } \\
\text { escape from complement-mediated killing }\end{array}$ & $\begin{array}{l}{[90,122} \\
146]\end{array}$ \\
\hline $\operatorname{lct} \mathrm{P}$ & Its inactivation results in C3-mediated cell lysis & $\begin{array}{c}{[102,147,} \\
148]\end{array}$ \\
\hline $\operatorname{lgt} \mathrm{A}, \lg t \mathrm{~B}, \lg t \mathrm{C}, \lg t \mathrm{D}, \lg t \mathrm{E}, \lg t \mathrm{G}$ & $\begin{array}{l}\text { They are involved in LOS biosynthesis and are phase-variable; for } \\
\text { example, lgtA or lgtC phase variation mediates LPS immunotype } \\
\text { switch from L3 to L8/L1 }\end{array}$ & {$[60]$} \\
\hline LOS/LPS & $\begin{array}{l}\text { It protects from macrophages; strains of the same species produce } \\
\text { different LOS glycoforms }\end{array}$ & {$[122]$} \\
\hline$l p t \mathrm{~A}$ & $\begin{array}{l}\text { It adds a phosphoethanolamine group to lipid A and confers } \\
\text { resistance to defensins and cathelicidins }\end{array}$ & {$[90,149]$} \\
\hline Lst & $\begin{array}{l}\text { LOS sialylation (by the enzyme Lst) prevents complement } \\
\text { deposition and phagocytosis by neutrophils }\end{array}$ & {$[122,150]$} \\
\hline mes $\mathrm{J}$ & It is phase-variable & [49] \\
\hline Msf & It binds to vitronectin; it increases serum resistance & {$[151]$} \\
\hline Mip & It tunes gene expression & $\begin{array}{l}{[102,152,} \\
153]\end{array}$ \\
\hline misR, misS & $\begin{array}{l}\text { They are phase-variable; they are involved in capsule regulation } \\
\text { and modification }\end{array}$ & {$[114,154]$} \\
\hline mltA (formerly known as GNA33) & It tunes gene expression & {$[155]$} \\
\hline$m n t \mathrm{~A}, m n \mathrm{tB}, m n t \mathrm{C}$ & They protect against oxidative stress & {$[122,156]$} \\
\hline $\bmod \mathrm{A}, \bmod \mathrm{B}$ & They are phase-variable & {$[34]$} \\
\hline$m s r \mathrm{~A}, m s r \mathrm{~B}$ & $\begin{array}{l}\text { They are involved in the methionine sulfoxide reduction and they } \\
\text { repair oxidized proteins }\end{array}$ & {$[122,157]$} \\
\hline$m t r \mathrm{C}, m t r \mathrm{D}, m t r \mathrm{E}$ & $\begin{array}{l}\text { They protect against cationic antimicrobial peptides and toxic } \\
\text { hydrophobic molecules }\end{array}$ & $\begin{array}{l}{[122,158,} \\
159]\end{array}$ \\
\hline$n a d A$ and its regulator $n a d \mathrm{R}$ & $\begin{array}{l}\text { It binds to Hsp90, recruits ARF6 and Rab1l, and activates human } \\
\text { monocytes and macrophages, triggering IFN-gamma and R-848 } \\
\text { dependent pathways; it interacts with betal integrins; it is } \\
\text { phase-variable }\end{array}$ & $\begin{array}{l}{[39,160-} \\
165]\end{array}$ \\
\hline nalP & $\begin{array}{l}\text { An autotransporter protease: it cleaves C3, facilitates degradation } \\
\text { of C3b, and enhances Neisserial survival in human serum; it } \\
\text { stabilizes the biofilm; moreover, it is involved in the processing of } \\
\text { other proteases, such as the proteases which release LbpB, whose } \\
\text { release enables Neisseria to escape from complement-mediated } \\
\text { killing; NalP processes also App and IgA1 protease; it has an } \\
\text { important role in the virulence of the pathogen }\end{array}$ & $\begin{array}{l}{[24,102,} \\
166]\end{array}$ \\
\hline Nhba (formerly known as GNA2132) & It tunes gene expression & [167] \\
\hline$n h h A$ & $\begin{array}{l}\text { It activates TLR4-dependent and independent pathways; it triggers } \\
\text { apoptosis in macrophages; it increases serum resistance and } \\
\text { protects from phagocytosis and complement attack; it is essential } \\
\text { for colonization }\end{array}$ & {$[168,169]$} \\
\hline
\end{tabular}


TABle 2: Continued.

\begin{tabular}{|c|c|c|}
\hline N. meningitidis molecule & Immunological role & Reference \\
\hline nifS & It is phase-variable & {$[49]$} \\
\hline nirK & $\begin{array}{l}\text { It protects Neisseria from nitrosative stress during colonization and } \\
\text { invasion }\end{array}$ & {$[170,171]$} \\
\hline nor B & $\begin{array}{l}\text { It favours the pathogen growth, enabling utilization and } \\
\text { consumption of NO during microaerobic respiration, enhances } \\
\text { pathogen survival, protects Neisseria from nitrosative stress during } \\
\text { colonization and invasion, decreases and downregulates the } \\
\text { production of NO-regulated cytokines, such as TNF-alpha, IL-12, } \\
\text { IL-10, CCL5 (RANTES), and CXCL8 (IL-8), and prevents host cell } \\
\text { S-nitrosothiol formation }\end{array}$ & $\begin{array}{c}{[100,119} \\
120,170,172]\end{array}$ \\
\hline$n s p \mathrm{~A}$ & It binds to factor $\mathrm{H}$ and inhibits $\mathrm{AP}$ & $\begin{array}{l}{[122,173-} \\
175]\end{array}$ \\
\hline$n s r \mathrm{R}$ & $\begin{array}{l}\text { It is involved in denitrification metabolism and protects Neisseria } \\
\text { against nitrosative stress }\end{array}$ & {$[176,177]$} \\
\hline oat $\mathrm{W}$, oat $\mathrm{Y}$ & They tune gene expression & {$[178]$} \\
\hline Opa & $\begin{array}{l}\text { It interacts with CEACAM, promoting endothelial cell attachment } \\
\text { and upregulating endoglin (CD105) and cooperation with } \beta 1 \\
\text { integrins; it elicits innate host defences and actively suppresses } \\
\text { adaptive immune responses that would eliminate the pathogen }\end{array}$ & {$[179-184]$} \\
\hline Opc & $\begin{array}{l}\text { It binds to vitronectin, it inhibits AP, and it increases serum } \\
\text { resistance; it elicits innate host defences and actively suppresses } \\
\text { adaptive immune responses that would eliminate the pathogen }\end{array}$ & $\begin{array}{c}{[179-} \\
182,184]\end{array}$ \\
\hline $\operatorname{oxy} \mathrm{R}$ & $\begin{array}{l}\text { It regulates catalase expression and is involved in the protection } \\
\text { from oxidative stress }\end{array}$ & {$[185,186]$} \\
\hline P36 & It is involved in Neisserial adhesion. & [187] \\
\hline pacA, pacB & $\begin{array}{l}\text { They are involved in the composition and regulation of } \\
\text { peptidoglycan membrane }\end{array}$ & {$[188]$} \\
\hline$p g l \mathrm{~A}, p g l \mathrm{~B}, p g l \mathrm{G}, p g l \mathrm{H}$ & They are phase-variable & {$[60-62]$} \\
\hline Pili & $\begin{array}{l}\text { They alter the expression levels of human genes known to regulate } \\
\text { apoptosis, cell proliferation, inflammatory response, adhesion, and } \\
\text { genes for signaling pathway proteins such as TGF-beta/Smad, } \\
\text { Wnt/beta-catenin, and Notch/Jagged }\end{array}$ & {$[189]$} \\
\hline pilC1 & $\begin{array}{l}\text { It interacts with mucosal surface and mediates the crossing of the } \\
\text { BBB }\end{array}$ & {$[41,169]$} \\
\hline Pile, pils & $\begin{array}{l}\text { They are involved in nonreciprocal recombination-based antigenic } \\
\text { variation }\end{array}$ & {$[76]$} \\
\hline Pile, pilV & $\begin{array}{l}\text { They bind to CD147 for vascular colonization; they mediate also } \\
\text { Neisseria internalization }\end{array}$ & {$[190,191]$} \\
\hline pilP, pilQ & $\begin{array}{l}\text { They are involved in pilus biogenesis and outer membrane } \\
\text { stabilization }\end{array}$ & {$[51,192]$} \\
\hline porA & $\begin{array}{l}\text { It binds to } \mathrm{fH}, \mathrm{C} 3 \mathrm{~b}, \mathrm{C} 4 \mathrm{~b} \text {, and } \mathrm{C} 4 \mathrm{bp} \text { (more strongly under } \\
\text { hypotonic conditions); it increases serum resistance; it is involved } \\
\text { in phase variation }\end{array}$ & $\begin{array}{l}{[122,139,} \\
173]\end{array}$ \\
\hline por B & $\begin{array}{l}\text { It inhibits factor H-dependent AP; it interacts with TLR1 and TLR2 } \\
\text { and activates I } \kappa \text { B, MAPK/MAPKK, and PTK pathways, leading to } \\
\text { CD86 upregulation, to IL-6, IL-12, and TNF secretion in B cells } \\
\text { and DCs, and to IgB secretion in B cells }\end{array}$ & {$[122,173]$} \\
\hline$p p t \mathrm{~A}$ & It is phase-variable & {$[47]$} \\
\hline$P p x$ & $\begin{array}{l}\text { It is an exopolyphosphatase whose mutation protects Neisseria } \\
\text { from complement-mediated killing; it interacts with the AP of the } \\
\text { complement activation }\end{array}$ & [64] \\
\hline$r m p \mathrm{M}$ & It is involved in phase variation and modulation & {$[193,194]$} \\
\hline
\end{tabular}


TABLE 2: Continued.

\begin{tabular}{ll}
\hline N. meningitidis molecule & Immunological role \\
\hline Sialic acid synthase $(n e u \mathrm{~B}, \operatorname{siaA}, \operatorname{siaB}, \operatorname{siaC}, \operatorname{syn} \mathrm{C})$ & They are phase-variable \\
\hline $\operatorname{sod} \mathrm{B}, \operatorname{sod} \mathrm{C}$ & $\begin{array}{l}\text { They protect from phagocytosis by human } \\
\text { monocytes/macrophages }\end{array}$ \\
\hline$t b p A, t b p B($ also known as $t b p 1, t b p 2)$ & They are involved in nutritional immunity \\
\hline$T d f F$ & $\left.\begin{array}{l}\text { It is involved in intracellular iron acquisition and is found only in } \\
\text { genomes of pathogen strains }\end{array}\right]$ \\
\hline
\end{tabular}

Temperature sensors (such as RNA thermosensors

located in the $5^{\prime}$ UTRs of genes necessary for capsule Activated by coinfecting pathogens, they recruit mechanisms of biosynthesis, the expression of $\mathrm{fHbp}$, and sialylation of resistance and immunity escape LOS/LPS)

\begin{tabular}{ll}
\hline ton $\mathrm{B}$ & $\begin{array}{l}\text { It is involved in nutritional immunity, supplying energy to the } \\
\text { pathogen }\end{array}$ \\
\hline $\begin{array}{l}\text { Uncharacterized proteins (NGO1686, NMB0741, } \\
\text { NMB1436, NMB1437, NMB1438, and NMB1828) }\end{array}$ & $\begin{array}{l}\text { They protect from nonoxidative factors, but their mechanisms are } \\
\text { still not understood; NMB1436, NMB1437, and NMB1438 are } \\
\text { putatively involved in iron metabolism }\end{array}$ \\
\hline Uncharacterized factor (NMA1233) & It is involved in phase variation and modulation \\
\hline$x s e B$ & It is involved in phase variation \\
\hline$z n u D$ & It protects from neutrophils and nutritional immunity \\
\hline
\end{tabular}

Ab: antibody; AP: Alternative Pathway; ARF6: ADP-ribosylation factor 6; App: adhesion and penetration protein; BBB: blood-brain barrier; cbp: calprotectin binding protein; CEACAMs: carcinoembryonic antigen-related cell adhesion molecules; CRISPR: clustered regularly interspaced short palindromic repeats; ctr: capsule transport apparatus; dam: DNA adenine methyltransferase; drg: dam replacing gene; fur: ferric uptake regulator; ggt: gamma-glutamyl aminopeptidase; hsp: heat-shock protein; IgA: immunoglobulin A; lbp: lactoferrin binding protein; lct: lactate permease; LOS: lipooligosaccharide; Mip: macrophage infectivity potentiator; mltA: membrane-bound lytic transglycosylase A; IGR: intergenic region; Msf: meningococcal surface fibril; Msr: methionine sulfoxide reductase; NadA: Neisseria adhesion A; NhhA: Neisseria hia homologue A; oat: O-acetyltransferase; OMV: outer membrane vesicle; opa: opacity-associated protein a; opc: opacity-associated protein c; pac: peptidoglycan O-acyltransferase; pil: pilin; por: porin; RNA: ribonucleic acid; RNS: reactive nitrogen species; Sod: superoxide dismutase; SOMVs: spontaneously released OMVs; Tbp: transferrin-binding protein; TLR: toll-like receptor; UTRs: untranslated regions; uvr: ultraviolet resistant.

cationic antimicrobial peptides (CAMPs), including cathelicidin [196]. Conversely, the presence of capsular polysaccharide restrains the invasion and colonization of the nasopharyngeal barrier by hiding the adhesins and invasins of the meningococcus $[143,158]$. On the other hand, the presence of the capsule may allow the microorganism to pass unharmed through the intracellular environment by exploiting the system of cell microtubules, at least in the case of serogroup B $N$. meningitidis [197]. Moreover, the CP is essential for meningococcal growth and survival in the bloodstream and cerebrospinal fluid, increasing serum resistance. During the different stages of infection, the capsule may hinder or promote the survival of N. meningitidis in the human host; indeed, the microorganism can modulate the production of capsule components, which depends on 4 genes, three of whichsia $\mathrm{A}, s i a \mathrm{~B}$, and siaC-are situated in the cps locus. The sia $\mathrm{D}$ gene induces the production of polysialyltransferase, which allows the polymerization of sialic acid. For instance, in the early stages of infection, the production and assembly of sialic acid are downregulated [198]. Another example of polysialyltransferase system is given by oatWY [178].

In addition to the above-mentioned actions, the most important virulence activity of the CP is probably the significant impairment of both Neisserial adherence to DCs and the phagocytic killing of bacteria; indeed, the CP inhibits both the opsonic and the nonopsonic phagocytosis of $N$. meningitidis [199]. It prevents the formations of effective Abs against $N$. meningitidis.
CP downregulates both classical and alternative complement pathways and prevents the proper insertion of the membrane attack complex (MAC) [200, 201]. LPS also contributes to inhibiting MAC deposition [201, 202].

Moreover, $\mathrm{CP}$ switching contributes to escaping detection and killing. This is a complex phenomenon due to microevolution and usually involves Neisserial strains expressing sialic acid (e.g., the shift from serogroup B to C, from serogroup C to $\mathrm{W}-135$, from serogroup $\mathrm{Y}$ to $\mathrm{W}-135$, and from serogroup $\mathrm{Y}$ to $\mathrm{B})[79-82,203]$. The molecular basis is provided by the allelic replacement of the sialic acid CP polymerase.

Surprisingly, nanostructured materials such as multiwalled carbon nanotubes (MWNTs) and mesoporous silica have been found to increase Neisseria's transformational capacity $[83,84]$.

3.3. Major and Minor Adhesion Mechanisms of N. meningitidis. $N$. meningitidis possesses a multifaceted system of adhesins, such as pili and other systems of adhesion (i.e., opacity-associated proteins $\mathrm{OpA}$ and $\mathrm{OpC}$ ). Adhesion is probably a coordinated process mediated first by pili, which are composed of several proteins; the most important of these is Pilin E (PilE) [204], but Pilin C (PilC) [205] and the secretin Pilin Q (PilQ) [206] have also been described. PilE is the main constituent of the Neisseria type IV pilus. In 1984, Diaz et al. identified proteins I and II as the main components of the type IV pili and noted that Abs against protein I were highly specific [207]. Subsequently, Pilin E was classified as 
belonging to class I and class II. Class I Pilin E is highly variable, while class II Pilin E is highly conserved [208, 209]. For this reason, class II Pilin E has been suggested as a candidate antigen for a vaccine against meningococci [147]. The regulation of pilin genes is quite complex $[97,115,116,190]$.

Other components are as follows: pilV [210], pilP, pilD (a prepilin-processing leader peptidase), pil $\mathrm{F}$ and pilT (traffic NTPases), pilG (involved in the pilus assembly), pilM (pilus biogenesis protein), and pilW (involved in the pilus stabilization) [148], among others.

Although the interactions between type IV pili and cellular receptors are not completely known, they may interact with a membrane cofactor protein, named CD46 receptor, and with alpha 1 and alpha 2 integrins [211]. However, it is known that pili contribute to the aggregation of Neisserial cells [212]. This fact, associated with the ability of pili to act as a signalling protein by interacting directly with the $\beta 2$ adrenergic receptor, contributes to the depletion of junction proteins, thus helping meningococcus to pass through the epithelial and endothelial cells and, subsequently, to cross the blood-brain barrier (BBB) $[75,213]$.

Although pili are essential to the first phase of Neisserial adhesion to the cells of the airways, other adhesion molecules, such as LPS and porin A, intervene to strengthen the microbial bond. In particular, OpcA and OpcC appear to be very important; indeed, OpcA binds carcinoembryonic antigen cell adhesion molecules (CEACAMs), heparan sulphate proteoglycan (HSPG) and integrins [179-183, 214]. Opc proteins can combine with HSPGs and, through vitronectin and fibronectin, with their integrin targets. Furthermore, Opa proteins are able to elicit innate human defences that favour the survival of $N$. meningitidis, while actively suppressing adaptive immune responses that would eliminate the pathogen [184]. The variability of the expression of different Opa proteins could play a major role in prolonging the state of infection by circumventing the humoral host immune response [215].

The adhesion and penetration protein (app) [103], which is a member of the autotransported family of secreted proteins, owes its name to its ability to adhere to human cells, thereby favouring the entry of Neisseriae. To circumvent the immune system, meningococci possess formidable machineries that allow them to secrete proteins in different manners; in particular, Neisseriae mainly use the autotransporter pathway (also known as type $\mathrm{V}$ secretion system) [216]. The first-described protein belonging to the autotransporter superfamily was an $\operatorname{IgA}$ protease from $N$. gonorrhoeae [217]. MspA (meningococcal serine protease A) is another putative autotransporter protein. Not all strains of Neisseria gonorrhoeae/meningitidis possess the gene for MspA/AusI (also known as NMB1998). However, Turner et al. [218] demonstrated that convalescent sera from subjects affected by serogroup B invasive disease recognized the MspA antigen. NhhA (Neisseria hia/hsf homologue A, also known as Hsf) and Neisserial adhesin A (NadA) also belong to the autotransporters. Nhha contributes to bacterial adhesion by binding heparin sulphate and laminin. In addition, through the activation of caspase, NhhA increases the rate of macrophage apoptosis $[168,219]$. NadA, which is expressed by $50 \%$ of virulent strains [160], but only by $5 \%$ of the strains isolated from carriers, is of particular interest because it is one of the components of the $4 \mathrm{CMenB}$ (Bexsero) vaccine and binds betal integrins [220].

3.4. N. meningitidis: Avoidance Mechanisms against Reactive Oxygen Species (ROS), Reactive Nitrogen Species (RNS), and Antimicrobial Peptides (AMPs). When in contact with the mucosa of the nasopharynx, $N$. meningitidis can implement several strategies of adhesion, but it must overcome many barriers of innate immunity. We have already mentioned how the capsule allows bacteria to mitigate the activity of DCs. However, it must elude other substances, such as the reactive oxygen species and reactive nitrogen species produced by macrophages and the antimicrobial peptides produced by activated neutrophils. As already mentioned, the capsule protects $N$. meningitidis from LL-37 cathelicidin, but LPS also contributes to the resistance of the bacterium against this cathelicidin [156].

Furthermore, the toxic action of ROS is neutralized by the secretion of enzymatic proteins, such as catalase and superoxide dismutase $[144,149,221]$. The gene that codes for catalase is katA and is regulated by OxyR $[185,186,222]$, while SodB and SodC code for superoxide dismutase [223]. Laz, a lipid-modified azurin, protects the pathogen against $\mathrm{H}_{2} \mathrm{O}_{2}$ and cupper toxicity $[135-138,145,176]$.

In addition, $N$. meningitidis possesses genes, which encode enzymes able to exert a denitrification action, such as aniA, CycP, nirK, nsrR, and norB. They favour the growth of the pathogen, enabling utilization and consumption of $\mathrm{NO}$ during microaerobic respiration, enhance pathogen survival, and protect Neisseria from nitrosative stress during colonization and invasion by preventing host cell S-nitrosothiol formation. Moreover, they reduce and downregulate the production of NO-dependent cytokines, such as TNF-alpha, IL-12, IL-10, CCL5 (RANTES), and CXCL8 (IL-8) [100, 101, $119,120,130,157,170,172,177,224]$.

Contemporarily, already at the level of the mucosa, the microorganism must resist the complement system.

Another interesting mechanism is the strategy whereby $N$. meningitidis escapes the attempts of the host to sequester nutrients essential for growth and survival of the pathogen. This process has been termed "nutritional immunity" [131, 139]. The microbe is endowed with OM receptors (such as HmbR, HpuA or HpuB, TbpA or TbpB, and TdfF) for acquiring iron and other important metals $[93,124,125,128,129,140$, $195,225]$. ZnuD is a high-affinity zinc uptake receptor, which plays an important role in enabling the pathogen to evade neutrophil-mediated killing [226, 227]. CbpA, a receptor for calprotectin, a protein released by neutrophils during inflammatory processes, is upregulated when $N$. meningitidis suffers from zinc limitation [226, 227]. Further examples of metabolic enzymes involved in nutritional immunity are glutamate transporters or molecules taking part in the carbon cycle [132-134, 228-230].

3.5. How Meningococcus Circumvents the Complement System. Three pathways can activate the complement functions, namely, the classic pathway, the alternative pathway, and 
the lectin pathway. All three of these pathways contribute to the transformation of C3 to C3b [231].

The alternative pathway acts by comparing self- with nonself-antigens and is activated by anything that differs from the markers of host cells. Specifically, factor $\mathrm{H}$ recognizes hostassociated molecular patterns (HAMPs). Properdin, first identified in 1959, is another protein that can directly activate the alternative pathway of the complement system [232]. It has been demonstrated that properdin deficiency favours recurrent episodes of $N$. meningitidis infection [233].

Meningococci produce three different variants $(1,2$, and 3 ) of a protein that binds factor $\mathrm{H}$. This protein, named $\mathrm{fHbp}$ (factor $\mathrm{H}$ binding protein) or GNA1870, blocks activation of the alternative pathway of the complement system. Indeed, by surrounding themselves with fHbp, $N$. meningitidis cells capture and inactivate factor $\mathrm{H}$. Thus, it is easy for the microorganism to survive and reproduce, especially in the bloodstream and cerebrospinal fluid. Hence, it is important that the $4 \mathrm{CMenB}$ (Bexsero) vaccine contains variant 1 of this protein, which is often expressed by virulent meningococcal strains [228]. Another vaccine (Trumenba), recently licensed in the USA, contains recombinant variants 1 and 2 of $\mathrm{fHbp}$ from N. meningitidis serogroup B, A and B subfamilies (A05 and $\mathrm{B} 01$, resp.) $[234,235]$. The proteins are produced by exploiting an advanced genetic engineering technique, using E. coli as a vector.

\subsection{The Adaptive Immune Response against Neisseria menin-} gitidis. Microorganisms such as N. meningitidis are able to change many exposed surface proteins, while the polysaccharides, which constitute the capsule, are T-independent (TI-2) antigens and can activate B cells directly, without the intervention of the MHC. However, TI-2 antigens do not induce an efficient secondary response and do not induce the production of avid immunoglobulins. Rather, they induce the production of short-lived Abs belonging to the IgM class [236].

In addition, it is important to consider that, in infants and children, the development of the immune system is a dynamic process, which begins in utero and continues for months and even years after birth. This explains why many components of the immune system are inefficient or partially efficient in infancy and early childhood [237-239]. For this reason, most cases of meningitis and sepsis from $N$. meningitidis occur under the age of 4 years and particularly in the first year of life.

The critical role of bactericidal Abs against the exposed surface antigens of $N$. meningitidis has been demonstrated by several studies. Indeed, Goldschneider et al. [240] showed that only individuals without bactericidal Abs contracted the clinical disease. In addition, the successful therapeutic use of immune sera, which markedly reduced lethality when first implemented by Flexner [241], has shown the central role of these Abs in protecting against invasive disease. The opsonic activity of Abs is also very important in the protection against and the recovery from meningococcal disease, as is demonstrated by the role of neutrophils, macrophages, and DCs in combating N. meningitidis. It is also well known that the cerebrospinal fluid of patients contains large numbers of neutrophils full of microorganisms. These clusterings of neutrophils are known as neutrophil extracellular traps
(NETs) and massively release cathepsin G. N. meningitidis circumvents these traps by blebbing spontaneously released OMVs (SOMVs). Other strategies that the pathogen exploits are modification of lipid A of LPS with phosphoethanolamine protected and upregulation of $\mathrm{ZnuD}$ [92].

The adaptive immune response has been studied in carriers and during both the invasive period leading to clinical meningitis and the convalescence period. T cell response is "two-faced"; while proinflammatory T cells may indeed blunt the invasive power of the pathogen, the induction of the Treg response, which is able to limit virulence, carries the price of the reduced effectiveness of the protective response, especially in children [242]. During infection, increased meningococcal antibody titres can be detected from the 4th day, peaking at the end of the third week or the beginning of the fourth week and showing a correlation with the severity of the disease and the age of the patient. In the acute period of the disease, the number of $\mathrm{T}$ cells generally drops, while that of B cells increases; by the end of the second week, IgG levels decline and IgM levels rise [243]. In particular, abnormalities in $\mathrm{T}$ cell response can be detected, such as an elevated percentage of CD25+ and HLA-DR+ T cells, an increase in CD4+ CD45R+ (suppressor-inducer) cells, with subsequent expression of activation antigens, and a decrease in CD4+ CDw29+ (helper-inducer) cells [244]. During convalescence, an age-associated Th response can be observed: specifically, a Th1 response (low IL-10/IFN- $\gamma$ ratio) and a highly proliferative Th2 response (higher IL-10/IFN- $\gamma$ ratio) can be detected in younger and older patients, respectively [245]. Generally, a significant $\mathrm{CD} 4+\mathrm{T}$ central memory response, with serum bactericidal antibodies, a marker of protective immunity, can be found [246]. However, the above-mentioned age-related mucosal $\mathrm{T}$ effector/memory cell response may also be present without bactericidal antibodies [247].

3.7. Other Immunoescape Strategies. Temperature fluctuation plays an important, although underscored, role in microbial pathogenesis, colonization, invasion, and host evasion. In contrast to mammals that maintain constant body temperature, pathogens' and other animals' temperature oscillates on a daily basis. Loh and collaborators [99] have identified the molecular bases of this temperature-dependent strategy. They have studied three RNA thermosensors located in the $5^{\prime}$ untranslated regions (UTRs) of genes involved in the $\mathrm{CP}$ biosynthesis, the expression of $\mathrm{fHbp}$, and sialylation of LOS/LPS. Increased temperature (e.g., during inflammation by coinfecting pathogens, such as influenza virus) "alarms" the meningococcus and triggers its defence mechanisms against human immune killing. This could be a key determinant for the transformation of a symbiont pathogen into a virulent one. However, the precise nature of this mechanism remains elusive.

Clustered regularly interspaced short palindromic repeats- (CRISPR-) Cas9 is another molecular tool that Neisseria can use in order to divert immune surveillance. It is an intrinsically ambivalent device, since, on one hand, being involved in gene expression and regulation, it restricts the possibility of editing the Neisseria genome via HGT/LGT or the insertion of exogenous nucleic material, and therefore it 
limits the microbial variability. On the other hand, CRISPRCas9-mediated repression of bacterial lipoprotein expression facilitates evasion of TLR2 by the pathogen [112].

Another mechanism is the molecular decoy, with which the microbe deceives the human immune system. For example, $f p r B$ has an antigenic subdomain for binding antibodies, which is not essential for the functioning the autotransporter [94].

The example of $f p r B$ is useful to show how Neisseria can use concurrently the previously described immunoescape strategies: $f p r \mathrm{~B}$ is subject to a high degree of antigenic variation, is a phase-variable gene, is involved in nutritional immunity, and moreover exploits a molecular decoy. Neisserial carbohydrates, mimicking host carbohydrates, circumvent immune system and at the same time exploit their mimicry to recruit fH [91].

\section{Meningococcal Vaccines}

4.1. Polysaccharide Vaccines. As at least six meningococci are pathogenic in humans, the development of meningococcal vaccines has been a challenge. The first step towards solving the problem was to find a common denominator among antigens that showed high variability. In 1969, Gotschlich et al. [248] correctly put the first imperfect piece of the puzzle in place by demonstrating the possibility to extract the capsule polysaccharide. However, although high molecular weight groups $\mathrm{A}$ and $\mathrm{C}$ meningococcal polysaccharides proved immunogenic in adults [249-251], important limitations of this vaccine emerged in subsequent years. Indeed, while both group A and group $\mathrm{C}$ vaccines proved effective in USA and Italian recruits $[252,253]$ after one administration, they displayed only short-term efficacy in older children and adults. Moreover, vaccines against serogroup $\mathrm{C}$ did not prevent disease in infants, and the efficacy of group A vaccines in children under 1 year of age was unclear. The immune response occurred 10 days after vaccination. In schoolchildren and adults, one dose of these vaccines seemed to provide protection for at least 3 years [254]. These findings are explained by the characteristics of the antigens contained in the vaccines. Indeed, polysaccharides with repeating epitopes induce an immune response with the following characteristics $[255,256]$ :

(i) The response occurs between the ages of 3 and 18 months but is variable; in children less than 2 years of age, the response is usually poor;

the affinity maturation of the Abs does not occur.

(ii) The immunologic memory is not stimulated.

(iii) Almost all ( $>90 \%)$ Abs produced belong to the IgM class and are produced in the spleen $[257,258]$. Furthermore, several studies have suggested that vaccination with large amounts of polysaccharides induces immune tolerance towards these antigens [259].

4.2. Polysaccharide Conjugate Vaccines. Three immunogenic carrier proteins are generally used inpolysaccharide conjugate vaccines, namely, diphtheria or tetanus toxoid, CRM197 (a nontoxic variant of diphtheria toxin obtained by molecular biology), and a complex of outer membrane protein (OMP) mixture from $N$. meningitidis. The toxoids were selected as carriers, firstly because of their immunological potency and secondly because if the recipient had previously been immunized with the toxoid, a booster effect was predictable. Moreover, under particular conditions, suppressive effects can also occur. The conjugate vaccine against $N$. meningitidis serogroup $\mathrm{C}$ had great success in several countries (UK, Netherlands, Spain, Italy, etc.) [260]. Today, tetravalent conjugate vaccines ACWY are also available in both the USA and Europe [260-262].

4.3. Vaccines against $N$. meningitidis Serogroup B. The most difficult problem was to prepare a vaccine against $N$. meningitidis serogroup B strains. Indeed, the maximum expression of camouflage is found in the capsule of these strains. Specifically, the polysaccharide of serogroup B meningococcal strains is a homopolymer of sialic acid residues and has structural similarities to brain glycoproteins. For this reason, it was impossible to prepare a polysaccharide antimeningococcus B vaccine. To overcome this obstacle, OMVs-vaccines were developed and used during epidemics caused by $N$. meningitidis serogroup B strains. However, given the high variability of the proteins, such as porins, present in OMVs, these vaccines were effective only against very specific epidemic hypervirulent strains $[263,264]$. In order to develop a vaccine against meningococcus $B$, other strategies were therefore implemented.

The most promising results were obtained through reverse vaccinology. This involves identifying the antigens for the vaccine not in the classic way-that is, from the components of the bacterium-but instead from the genes that express the proteins with the best characteristics to be good antigens for the vaccine. To obtain a universal vaccine against serogroup B meningococcal strains, complex bioinformatics software was also applied. Following the complete sequencing of the meningococcus B genome [265], researchers at Novartis Vaccines and Diagnostics identified 600 ORFs, which expressed proteins that are exposed on the surface of the bacterial cell. Subsequently, 350 proteins were successfully expressed in E. coli, purified, and used to immunize mice. Later, 28 novel protein antigens able to elicit Abs with bactericidal activity were identified. Finally, three of these 28 proteins were selected, namely, NHBA (GNA2132, fused with GNA1030 protein), fHbp (fused with GNA2091 protein), and nadA. NHBA (Neisseria heparin binding antigen), which is present in virtually all strains, binds heparin, which may increase the serum resistance of bacteria. fHbp (factor $\mathrm{H}$ binding protein) binds factor $\mathrm{H}$, which enables the bacterium to survive in theblood [266, 267], thereby blocking the alternative pathway of the complement system. nadA (Neisserial adhesin A) promotes adherence to and invasion of human epithelial cells $[161,162]$. In addition, the vaccine developed by Novartis Vaccines and Diagnostics contains a fourth component, namely, the vesicle of the OM from the New 
Zealand strains, which contain porin 1.4. Theoretically, this vaccine should elicit bactericidal Abs against the following:

(i) NHBA, thus increasing the bactericidal activity of the serum.

(ii) fHbp, thus exposing N. meningitidis to the alternative pathway of the complement system.

(iii) $\mathrm{NadA}$, thus hindering the adherence of N. meningitidis to epithelial cells.

(iv) Porin A 1.4 and other components of the mixture of proteins contained in OMVs; indeed, OMVs can enhance the immune response by functioning as a conjugate complex of proteins or, rather, a complex of adjuvants.

Several clinical trials have demonstrated the immunogenicity and safety of this vaccine, also named $4 \mathrm{CMenB}$, in infants, children, adolescents, and adults [268, 269]. Consequently the vaccine has been approved by the EMA and named Bexsero [270]. It has also been approved by several national drug agencies (such as FDA), including the Agenzia Italiana del Farmaco (AIFA, Italian National Agency for Drugs) [271].

Owing to the wide variability of Neisserial antigens, a particular laboratory test (MATS) has been developed to estimate the potential effectiveness of the vaccine. Studies conducted worldwide have shown the potential effectiveness of Bexsero, which has been estimated at $87 \%$ in Italy [85].

Trumenba was approved for individuals aged 10 to 25 years in the USA in October 2014 [85]. The potential of the vaccine antigen was tested in the laboratory [272] and on a murine model $[273,274]$. The immunogenicity, safety, and tolerability of this vaccine were investigated in a randomized controlled trial in infants aged 18-36 months, who were subdivided into three cohorts (receiving 20-, 60-, and 200$\mu \mathrm{g}$ rLP2086 dose, resp.) and matched with two control groups: one vaccinated against hepatitis A virus (HAV) and the other with a saline placebo. After the vaccination cycle, seroconversions against Neisserial strains expressing LP2086 variants homologous to the vaccine antigens were found in $61.1-88.9 \%$ of toddlers and against strains expressing heterologous LP2086 variants in 11.1-44.4\%. Adverse reaction rates were negligible and the vaccine proved to be safe and well tolerated [275]. However, another randomized phase 1/2 clinical study found high fever rates in toddlers receiving one 20- or 60- $\mu$ g rLP2086 dose (64\% and 90\%, resp.) [276].

In a randomized study performed in the USA and Europe in a sample of adolescents (11-18 years of age), Trumenba proved to be highly immunogenic. The proportion of vaccinees with human serum bactericidal activity (h-SBA) titres with a $\geq 4$-fold rise against hypervirulent Neisserial strains with different variants of $\mathrm{fHbp}$ was in the range of $75-100 \%$. In another randomized clinical study, carried out in Australia, the safety and immunogenicity of the vaccine were assessed in 60 healthy adults (18-40 years of age) who received $120 \mu \mathrm{g}$ doses at 0,1 , and 6 months. The percentage of seroprotected vaccinees was $94.3 \%$ against the homologous strains and $70-$ $94.7 \%$ against the heterologous strains. The vaccine was well tolerated $[277,278]$.
As fHbp is also expressed by Neisserial serogroups other than B, the anti-fHbp Abs elicited by rLP2086 might exert a bactericidal effect on meningococci, such as those against $N$. meningitidis serogroup $\mathrm{C}$, as proved by Harris and collaborators [279] and by Konar and colleagues [280]. Moreover, there is some evidence that Trumenba could, at least in part, have an effect on carriage and reduce the risk of acquiring some hypervirulent strains [281].

4.4. New Vaccines. The currently available Neisseria vaccines, described in the previous paragraphs, are reported and summarized in Table 3.

The elucidation of immunoescape strategies and genomics have enabled scholars to discover new potential vaccine candidates, like NMB0928 [282] or NMB1468 [283], FrpB/fetA [125], LbpA and LbpB [284], adhesin complex protein (ACP) [285], NspA [286, 287], MIP [152], ZnuD [93], PilE [76] and PilQ [288], IgA protease [289], T cell stimulating protein A ( $t s p \mathrm{~A})$ [289], or the CP polymerase of Neisseria serogroup X [290], among others [291].

Reverse vaccinology has proved to be a promising approach, enabling researchers to develop the effective vaccine Bexsero. New highly integrated approaches, which combine genomics with postgenomics, are leading to nextgeneration vaccines. A combination of reverse and forward vaccinology techniques, such as immunoproteome investigation via combined cell surface immunoprecipitation and mass spectrometry (MS) [153], and new bioinformatics strategies, such as the protectome approach [292], are promising in identifying highly conserved motifs in known bacterial protective antigens and using them for the design of effective universal vaccines [293, 294].

\section{Conclusions}

The development of effective vaccines against meningococcal disease has been a long and hard struggle. Early efforts yielded only partial results, with the creation of polysaccharide vaccines [295]. Subsequent research, however, led to the production of the conjugate vaccines [296]. Today, we have the conjugate meningococcal C vaccines [297], an affordable conjugate vaccine against $N$. meningitidis serogroup A (MenAfriVac) [298, 299], the tetravalent conjugate vaccines [270], and, finally, two "universal" vaccines against meningococcal group B strains [300, 301]. The critical rate of coverage required in order to eliminate the disease is probably not among the highest [302]. Indeed, the conjugate vaccine for serogroup $\mathrm{C}$ has resulted in dramatic reductions of cases of the disease [303] and created herd immunity that seems to have had a significant effect on the carrier status of adolescents and young adults. Thus, the prospect of dominating this very serious disease lies decidedly in the medium term.

However, it must be borne in mind that we are immersed in a constellation of Neisseriae, whose only survival niche is man. Although Neisseriae such as N. lactamica, N. sicca, $N$. elongata, $N$. cinerea, and $N$. flavescens are usually able to establish silent infection in normal humans, it is not inconceivable that, given the microorganism's great capacity 
TABLE 3: An overview of the currently available Neisseria meningitidis vaccines.

\begin{tabular}{|c|c|c|c|c|c|}
\hline Vaccine & Manufacturer & Serogroups & Licensed age group & $\begin{array}{l}\text { Administration } \\
\text { schedule }\end{array}$ & Components details \\
\hline AC Vax & $\begin{array}{l}\text { GlaxoSmithKline, } \\
\text { UK }\end{array}$ & $\mathrm{A}, \mathrm{C}$ & $2 \mathrm{y}+$ & Single dose & $\begin{array}{c}50 \mu \mathrm{g} \text { each of meningococcal } \\
\text { polysaccharides }\end{array}$ \\
\hline ACWY Vax & $\begin{array}{l}\text { GlaxoSmithKline, } \\
\text { UK }\end{array}$ & $\begin{array}{l}\mathrm{A} / \mathrm{C} / \mathrm{Y} / \mathrm{W}- \\
135\end{array}$ & $\begin{array}{l}2 \mathrm{y}+\text {; can be given } \\
\text { also at } 2 \mathrm{mo}+\text {, even } \\
\text { though less } \\
\text { protective against } \\
\mathrm{C}, \mathrm{Y} \text {, and } \mathrm{W}-135\end{array}$ & Single dose & $\begin{array}{c}50 \mu \mathrm{g} \text { each of meningococcal } \\
\text { polysaccharides }\end{array}$ \\
\hline $\begin{array}{l}\text { Bexsero } \\
(4 \mathrm{CMenB})\end{array}$ & $\begin{array}{l}\text { Novartis Vaccines } \\
\text { and Diagnostics }\end{array}$ & B & $2 \mathrm{mo}-17 \mathrm{y}$ & $\begin{array}{l}\text { Complex dose schedule } \\
\text { depending on age: } 3 \\
\text { doses }+ \text { booster for } \\
2-5 \text { mo; } 2 \text { doses }+ \\
\text { booster at } 6-23 \text { mo; } 2 \\
\text { doses at } 2+y\end{array}$ & $\begin{array}{c}50 \mu \mathrm{g} \text { of each recombinant NHBA, } \\
\text { NadA, fHbp fusion proteins, } \\
\text { OMVs from strain NZ98/254 } \\
\text { containing the PorA P1.4 ( } 25 \mu \mathrm{g}) \\
\text { adsorbed on } 0.5 \mathrm{mg} \mathrm{Al}^{3+}\end{array}$ \\
\hline $\begin{array}{l}\text { HexaMen and } \\
\text { HexaMix }\end{array}$ & $\begin{array}{l}\text { National Institute } \\
\text { for Public Health } \\
\text { and the } \\
\text { Environment, } \\
\text { Bilthoven, } \\
\text { Netherlands }\end{array}$ & B & - & $\begin{array}{l}2,3 \text {, and } 4 \mathrm{mo} \text {, a } \\
\text { booster dose at } \\
12-18 \mathrm{mo}\end{array}$ & $\begin{array}{c}\text { OMV from two recombinant } \\
\text { engineered strains, each of which } \\
\text { expressed three different PorA } \\
\text { subtypes (P1.5-2, 10; P1.12-1, 13; } \\
\text { P1.7-2, 4; P1.19, 15-1; P1.7, 16; and } \\
\text { P1.5-1, 2-2) }\end{array}$ \\
\hline $\begin{array}{l}\text { Menactra } \\
\text { (MenACWY-DT) }\end{array}$ & Sanofi Pasteur & $\begin{array}{l}\mathrm{A} / \mathrm{C} / \mathrm{Y} / \mathrm{W}- \\
135\end{array}$ & $9 \mathrm{mo}-55 \mathrm{y}$ & Single dose & $\begin{array}{c}4 \mu \mathrm{g} \text { each of meningococcal } \\
\text { polysaccharides conjugated to } \\
48 \mu \mathrm{g} \text { of a diphtheria toxoid } \\
\text { protein carrier }\end{array}$ \\
\hline $\begin{array}{l}\text { MenAfriVac } \\
(\text { MenA-TT) }\end{array}$ & $\begin{array}{l}\text { Serum Institute of } \\
\text { India }\end{array}$ & A & $1-29 y$ & Single dose & $\begin{array}{c}10 \mu \mathrm{g} \text { of meningococcal group A } \\
\text { polysaccharides conjugated to } 10 \\
\text { to } 33 \mu \mathrm{g} \text { tetanus toxoid }\end{array}$ \\
\hline MenBvac & $\begin{array}{l}\text { National Institute } \\
\text { for Public Health, } \\
\text { Norway, and } \\
\text { Novartis }\end{array}$ & B & - & $\begin{array}{l}3 \text { doses (interval } \\
5-12 \mathrm{w})\end{array}$ & $\begin{array}{l}\text { OMVs from the strain } 44 / 76 \\
\text { adsorbed on } \mathrm{Al}^{3+}\end{array}$ \\
\hline MencevaxA & $\begin{array}{l}\text { GlaxoSmithKline } \\
\text { and RIT, Belgium }\end{array}$ & A & $2 y+$ & Single dose & $\begin{array}{c}50 \mu \mathrm{g} \text { of meningococcal group A } \\
\text { polysaccharides } \\
\text { No conjugation }\end{array}$ \\
\hline MencevaxAC & GlaxoSmithKline & $\mathrm{A}, \mathrm{C}$ & $2 \mathrm{y}+$ & Single dose & $\begin{array}{c}50 \mu \mathrm{g} \text { each of meningococcal } \\
\text { group polysaccharides } \\
\text { No conjugation }\end{array}$ \\
\hline MencevaxACY & GlaxoSmithKline & A, C, Y & $2 y+$ & Single dose & $\begin{array}{c}50 \mu \mathrm{g} \text { each of meningococcal } \\
\text { group polysaccharides } \\
\text { No conjugation }\end{array}$ \\
\hline MencevaxACYW & GlaxoSmithKline & $\begin{array}{l}\mathrm{A} / \mathrm{C} / \mathrm{Y} / \mathrm{W}- \\
135\end{array}$ & $2 y+$ & Single dose & $\begin{array}{c}50 \mu \mathrm{g} \text { each of meningococcal } \\
\text { group polysaccharides } \\
\text { No conjugation }\end{array}$ \\
\hline $\begin{array}{l}\text { Mengivac A + C } \\
\text { (MenPS) }\end{array}$ & Sanofi Pasteur & $\mathrm{A}, \mathrm{C}$ & - & - & $\begin{array}{c}50 \mu \mathrm{g} \text { of meningococcal group C } \\
\text { polysaccharides }\end{array}$ \\
\hline $\begin{array}{l}\text { MenHibrix } \\
\text { (HibMenCY-TT) }\end{array}$ & GlaxoSmithKline & C, Y & $6 \mathrm{w}-18 \mathrm{mo}$ & $2,4,6$, and 12 to $15 \mathrm{mo}$ & $\begin{array}{l}\text { Meningococcal groups } \mathrm{C} \text { and } \mathrm{Y} \\
\text { polysaccharides conjugated to } \\
\text { tetanus toxoid }\end{array}$ \\
\hline $\begin{array}{l}\text { Meningitec } \\
\text { (MenC-CRM) }\end{array}$ & $\begin{array}{c}\text { Wyeth Vaccines, } \\
\text { Canada, UK, and } \\
\text { Australia }\end{array}$ & $\mathrm{C}$ & $2 \mathrm{mo}+$ & $\begin{array}{l}3 \text { doses at } 2-12 \mathrm{mo}, 1 \\
\text { dose at } 12 \mathrm{mo}+\end{array}$ & $\begin{array}{c}10 \mu \mathrm{g} \text { of meningococcal group C } \\
\text { polysaccharides conjugated to } \\
15 \mu \mathrm{g} \mathrm{CRM}_{197}\end{array}$ \\
\hline Meninvact & Sanofi Pasteur & $\mathrm{C}$ & $2 \mathrm{mo}+$ & $\begin{array}{l}2 \text { doses at } 2-12 \mathrm{mo}, 1 \\
\text { dose at } 12 \mathrm{mo}+\end{array}$ & $\begin{array}{c}\text { Meningococcal group C } \\
\text { polysaccharides conjugated to } \\
\mathrm{CRM}_{197}\end{array}$ \\
\hline
\end{tabular}


TABLE 3: Continued.

\begin{tabular}{|c|c|c|c|c|c|}
\hline Vaccine & Manufacturer & Serogroups & Licensed age group & $\begin{array}{l}\text { Administration } \\
\text { schedule }\end{array}$ & Components details \\
\hline $\begin{array}{l}\text { Menitorix } \\
(\text { Hib-MenC-TT) }\end{array}$ & GlaxoSmithKline & $\mathrm{C}$ & $6 \mathrm{w}-12 \mathrm{mo}$ & Booster at $1-2 y$ & $\begin{array}{c}\text { Meningococcal group C } \\
\text { polysaccharides conjugated to } \\
\text { tetanus toxoid }\end{array}$ \\
\hline $\begin{array}{l}\text { Menjugate } \\
\text { (MenC-CRM) }\end{array}$ & $\begin{array}{c}\text { Novartis Vaccines } \\
\text { and Diagnostics }\end{array}$ & $\mathrm{C}$ & $2 \mathrm{mo}+$ & $\begin{array}{c}3 \text { doses at } 2-12 \mathrm{mo} ; 1 \\
\text { dose at } 12 \mathrm{mo}+\end{array}$ & $\begin{array}{c}10 \mu \mathrm{g} \text { of meningococcal group } \mathrm{C} \\
\text { polysaccharides conjugated to } 12.5 \\
\text { to } 25 \mu \mathrm{g}^{\mathrm{CRM}} \mathrm{C}_{197}\end{array}$ \\
\hline Menomune & Sanofi Pasteur & $\mathrm{A}, \mathrm{C}$ & $2 y+$ & Single dose & $\begin{array}{c}50 \mu \mathrm{g} \text { each of meningococcal } \\
\text { group polysaccharides } \\
\text { No conjugation }\end{array}$ \\
\hline Menomune & Sanofi Pasteur & $\begin{array}{l}\mathrm{A} / \mathrm{C} / \mathrm{Y} / \mathrm{W}- \\
135\end{array}$ & $2 \mathrm{y}+$ & Single dose & $\begin{array}{c}50 \mu \mathrm{g} \text { each of meningococcal } \\
\text { group polysaccharides } \\
\text { No conjugation }\end{array}$ \\
\hline Menovac & Finlay Institute & $\begin{array}{c}\mathrm{A} / \mathrm{C} / \mathrm{Y} / \mathrm{W}- \\
135\end{array}$ & $2-55 y$ & Single dose & $\begin{array}{c}\text { Meningococcal group } \\
\text { polysaccharides }\end{array}$ \\
\hline $\begin{array}{l}\text { Menveo } \\
\text { (MenACWY- } \\
\text { CRM197) }\end{array}$ & $\begin{array}{c}\text { Novartis Vaccines } \\
\text { and Diagnostics }\end{array}$ & $\begin{array}{l}\mathrm{A} / \mathrm{C} / \mathrm{Y} / \mathrm{W}- \\
135\end{array}$ & $2-55 y$ & Single dose & $\begin{array}{c}10 \mu \mathrm{g} \text { of meningococcal group A } \\
\text { polysaccharides and } 5 \mu \mathrm{g} \text { of } \\
\text { meningococcal groups } \mathrm{C}, \mathrm{Y} \text {, and } \\
\mathrm{W}-135 \text { polysaccharides conjugated } \\
\text { to } \mathrm{CRM}_{197}\end{array}$ \\
\hline MeNZB & $\begin{array}{c}\text { Institute for } \\
\text { Public Health, } \\
\text { New Zealand, } \\
\text { Chiron, Novartis }\end{array}$ & B & - & - & OMVs from strain P1.7b, 4 \\
\hline $\begin{array}{l}\text { NeisVac-C } \\
\text { (MenC-TT) }\end{array}$ & Baxter BioScience & $\mathrm{C}$ & $2 \mathrm{mo}-65 \mathrm{y}$ & $\begin{array}{c}2 \text { doses at } 2-12 \mathrm{mo} \\
\text { (with an interval of at } \\
\text { least } 2 \mathrm{mo} \text { ), } 1 \text { dose at } \\
12 \mathrm{mo}+\end{array}$ & $\begin{array}{c}10 \mu \mathrm{g} \text { of meningococcal group C } \\
\text { polysaccharides conjugated to } \\
\text { tetanus toxoid }\end{array}$ \\
\hline Nimenrix & GlaxoSmithKline & $\begin{array}{l}\mathrm{A} / \mathrm{C} / \mathrm{Y} / \mathrm{W}- \\
135\end{array}$ & $1 \mathrm{y}+$ & Single dose & $\begin{array}{c}5 \mu \mathrm{g} \text { each of meningococcal group } \\
\text { polysaccharides conjugated to } \\
44 \mu \mathrm{g} \text { tetanus toxoid }\end{array}$ \\
\hline NmVac4 & $\begin{array}{c}\text { JN-International } \\
\text { Medical } \\
\text { Corporation } \\
\end{array}$ & $\begin{array}{c}\mathrm{A} / \mathrm{C} / \mathrm{Y} / \mathrm{W}- \\
135\end{array}$ & $2-55 y$ & Single dose & $\begin{array}{l}50 \mu \mathrm{g} \text { each of meningococcal } \\
\text { group polysaccharides }\end{array}$ \\
\hline Trumenba & Pfizer & $\mathrm{B}$ & $10-25 y$ & 3 doses $(0-2-6 \mathrm{mo})$ & $\begin{array}{l}120 \mu \mathrm{g} \text { of recombinant } \mathrm{fHbp} \\
\text { adsorbed on } 0.25 \mathrm{mg} \mathrm{Al}^{3+}\end{array}$ \\
\hline Zamevax & $\begin{array}{c}\text { Imunoloski } \\
\text { Zavod, Croatia }\end{array}$ & $\mathrm{A}, \mathrm{C}$ & - & - & No conjugation \\
\hline
\end{tabular}

$\mathrm{CRM}_{197}$ : cross-reacting material 197; fHbp: factor $\mathrm{H}$ binding protein; mo: month; NadA: Neisseria adhesion A; NHBA: Neisseria heparin binding antigen, also named GNA2132; OMV: outer membrane vesicle; PorA: porin A; w: week; y: year; $\mathrm{Al}^{3+}$ : Aluminum.

for genetic variation, nonpathogenic Neisseria might become hazardous to humans [304].

The challenge is still open.

\section{Abbreviations}

Abs: Antibodies

ACP: Adhesin complex protein

AIFA: Agenzia Italiana del Farmaco (Italian National Agency for Drugs)

AMPs: Antimicrobial peptides

AP: Alternative Pathway

app: Adhesion and penetration protein

ARF6: ADP-ribosylation factor 6
BBB: $\quad$ Blood-brain barrier

C3: $\quad$ Human complement 3 component

C3b: Human complement 3 b component

C4: $\quad$ Human complement 4

C4bp: $\quad$ Human complement $4 \mathrm{~b}$ binding protein

CAMPs: Cationic antimicrobial peptides

cas: $\quad$ CRISPR-associated

cbp: $\quad$ Calprotectin binding protein

CCL: $\quad$ Chemokine (C-C motif) ligand

CD: $\quad$ Cluster of Differentiation (CD4, CD25, CD45R, CD86, CD105, CD147, CDw29)

CDS: $\quad$ Coding sequence

CP: Capsule

CEACAMs: Carcinoembryonic antigen related cell adhesion molecules 
CMP-NANA: Cytidine monophosphoacetyl N-Acetylneuraminic acid

CRs: $\quad$ Correia repeats

CREEs: Correia repeat-enclosed elements

CRISPR: Clustered regularly interspaced short palindromic repeats

CRM197: Cross-reacting material 197

CRP:

CXCL:

DCs:

dam:

DNA:

drg:

dRS3:

E. coli:

EMA:

FDA:

fH:

fHbp:

fur:

GEI:

GGI:

ggt:

GNA:

C-reactive protein

Chemokine (C-X-C motif) ligand

Dendritic cells

DNA adenine methyltransferase

Deoxyribonucleic acid

Dam replacing gene

Duplicated repeat sequence 3

Escherichia coli

European Medicines Agency

Food and Drug Administration

Factor $\mathrm{H}$

Factor $\mathrm{H}$ binding protein

Ferric uptake regulator

Genomic island

Gonococcal genetic island

Gamma-glutamyl aminopeptidase

Genome-derived neisserial antigen

(GNA33, GNA1030, GNA1870, GNA2091,

GNA2132)

GWAS: Genome-wide association studies

HAMPs: Host-associated molecular patterns

HAV: Hepatitis A virus

HGT: Horizontal Gene Transfer

HLA: Human leukocyte antigens

hpu:

h-SBA:

HSP:

HSPG:

HTTs:

IFN:

$\operatorname{IgA}:$

IgG:

IgM:

IGR:

$\mathrm{I} \kappa \mathrm{B}:$

IL:

IM:

IS:

katA:

LAMP1:

lbp:

lct:

LGT:

$\operatorname{lgt}$ :

L-NNT:

LOS:

LPS:

MAC:

MAPK:

MAPKK:
Haemoglobin-haptoglobin utilization

Human serum bactericidal activity

Heat-Shock Protein

Heparan sulphate proteoglycan

High-throughput technologies

Interferon

Immunoglobulin A

Immunoglobulin G

Immunoglobulin $\mathrm{M}$

Intergenic region

Inhibitors of $\mathrm{NF}-\kappa \mathrm{B}$

Interleukin (IL6, IL8, IL10, IL12)

Inner membrane

Insertion sequence (IS1016, IS1106-like, IS1301, IS1655)

Catalase A

Lysosomal-associated membrane protein 1

Lactoferrin-binding protein

Lactate permease

Lateral Gene Transfer

Prolipoprotein diacylglyceryl transferase

$(\operatorname{lgt} \mathrm{A}, \operatorname{lgt} \mathrm{B}, \lg t \mathrm{C}, \operatorname{lgt} \mathrm{D}, \operatorname{lgt} \mathrm{E}, \lg t \mathrm{G})$

Lacto-N-neotetraose

Lipooligosaccharides

Lipopolysaccharides

Membrane attack complex

Mitogen-activated protein kinase

Mitogen-activated protein kinase Kinase
MATS: $\quad$ Meningococcal Antigen Typing System

MDA: Meningococcal disease-associated island

MHC: $\quad$ Major histocompatibility complex

MIP: $\quad$ Macrophage infectivity potentiator

MMEs: $\quad$ Minimal mobile elements

mltA: $\quad$ Membrane-boundlytic transglycosylase A

mo: Month

mRNA: messenger RNA

msf: $\quad$ Meningococcal surface fibril

$m s r: \quad$ Methionine sulfoxide reductase

MS: Mass spectrometry

mspA: $\quad$ Meningococcal serine protease A

$m t r: \quad$ Multiple transferable resistance

MWNTs: Multiwalled carbon nanotubes

N.: $\quad$ Neisseria (N. lactamica, N. sicca, N. elon-

gata, N. cinerea, and N. flavescens)

nadA: Neisserial adhesin A

NCAM-1: $\quad$ Neural cell adhesion molecule 1

NEMIS: Neisseria miniature insertion sequences

NETs: $\quad$ Neutrophil extracellular traps

NF- $\kappa$ B: $\quad$ Nuclear factor kappa-light-chain-enhancer of activated B cells

N. gonorrheae: Neisseria gonorrheae

NHBA: Neisserial heparin binding antigen

nhhA: Neisseria hia/hsf homologue

NIMEs: Neisserial intergenic mosaic elements

NKs: Natural killer cells

NLRs: NOD-like receptors

N. meningitidis: Neisseria meningitidis

NO: $\quad$ Nitric oxide

NOD: Nucleotide-binding Oligomerization

NTPase: $\quad$ Nomain $\quad$ Nucleoside triphosphatases

oat: O-acetyltransferase

OM: $\quad$ Outer membrane

OMPs: $\quad$ Outer membrane proteins

OMVs: $\quad$ Outer membrane vesicles

OMPLA: Outermembrane phospholipase A

Opa: Opacity-associated protein a

Opc: $\quad$ Opacity-associated protein c

ORF: Open reading frame

pac: $\quad$ Peptidoglycan O-acyltransferase

PAI: $\quad$ Pathogenic island

PAMPs: $\quad$ Pathogen-associated molecular patterns

pil: $\quad$ Pilin (pilC: OM/cell surface pilin; pilD: prepilin-processing leader peptidase; pilF: traffic NTPase; pilG: pilus assembly protein; pilM: biogenesis protein; pilP: pilot protein; pilQ: secretin; pilT: traffic NTPase; pilW: pilus stabilization protein)

PN: $\quad$ Peroxynitrite

por: $\quad$ Porin

pptA: $\quad$ Pilin phosphorylcholine transferase A

PRRs: Pattern recognition receptors

PTK: $\quad$ Protein tyrosine kinase

RANTES: $\quad$ Regulated on activation, normal $\mathrm{T}$ cell

RecA: Recombinase A 
REP2: Repetitive extragenic palindromic sequence

RIG-I: Retinoic acid-inducible gene 1

rLP2086: Recombinant lipoprotein 2086

RLRs: RIG-1-like receptors

RNA: Ribonucleic acid

RNS: $\quad$ Reactive nitrogen species

ROS: Reactive oxygen species

sia: $\quad$ Polysialic acid capsule biosynthesis protein (siaA, sia , sia $\mathrm{C}$, sia $\mathrm{D}$ )

SMAD: Small Mothers Against Decapentaplegic

sod: $\quad$ Superoxide dismutase ( $\operatorname{sodB}, \operatorname{sodC})$

SOMVs: Spontaneously released OMVs

SSM: $\quad$ Slipped strand mispairing

SSR: $\quad$ Simple Sequence Repeat

tbp: Transferrin-binding protein

TGF: Transforming Growth Factor

Th: T-cell helper

TI: T-cell Independent

TLR: Toll-like receptor (TLR2, TLR4, TLR5, TLR9)

TNF: Tumor Necrosis Factor

tspA: $\quad$ T cell stimulating protein A

UK: $\quad$ United Kingdom

USA: United States of America

UTR: Untranslated Region

w: Week

WGS: Whole-genome sequencing

WNT: Wingless-related integration site

y: $\quad$ Year

znuD: $\quad$ Zinc uptake component D.

\section{Conflict of Interests}

R. Gasparini, D. Panatto, N. L. Bragazzi, P. L. Lai, A. Bechini, M. Levi, P. Durando, and D. Amicizia declare that they have no conflict of interests regarding the publication of this paper.

\section{Acknowledgments}

Although efforts to make a systematic overview have been made as much as possible, quoting the relevant scholarly literature, due to the interdisciplinary nature of the topic and its vastity, the authors apologize if they have missed some important contributions. The authors thank Dr. Bernard Patrick for revising the paper.

\section{References}

[1] M. Murakami, T. Ohtake, R. A. Dorschner, B. Schittek, C. Garbe, and R. L. Gallo, "Cathelicidin anti-microbial peptide expression in sweat, an innate defense system for the skin," Journal of Investigative Dermatology, vol. 119, no. 5, pp. 1090-1095, 2002.

[2] D. R. Drake, K. A. Brogden, D. V. Dawson, and P. W. Wertz, "Thematic review series: skin lipids. Antimicrobial lipids at the skin surface," Journal of Lipid Research, vol. 49, no. 1, pp. 4-11, 2008.

[3] R. Medzhitov and C. Janeway Jr., "Innate immunity," The New England Journal of Medicine, vol. 343, no. 5, pp. 338-344, 2000.
[4] S. Galdiero, A. Falanga, M. Cantisani et al., "Microbe-Host interactions: structure and role of Gram-negative bacterial Porins," Current Protein and Peptide Science, vol. 13, no. 8, pp. 843-854, 2012.

[5] A. Di Donato, G. F. Draetta, G. Illiano, M. A. Tufano, L. Sommese, and F. Galdiero, "Do porins inhibit the macrophage phagocyting activity by stimulating the adenylate cyclase?" Journal of Cyclic Nucleotide and Protein Phosphorylation Research, vol. 11, no. 2, pp. 87-97, 1986.

[6] F. Galdiero, M. A. Tufano, L. Sommese, A. Folgore, and F. Tedesco, "Activation of complement system by porins extracted from Salmonella typhimurium," Infection and Immunity, vol. 46, no. 2, pp. 559-563, 1984.

[7] P. Massari, S. Ram, H. Macleod, and L. M. Wetzler, "The role of porins in neisserial pathogenesis and immunity," Trends in Microbiology, vol. 11, no. 2, pp. 87-93, 2003.

[8] K. Takeda and S. Akira, "Toll-like receptors in innate immunity," International Immunology, vol. 17, no. 1, pp. 1-14, 2005.

[9] F. Hayashi, K. D. Smith, A. Ozinsky et al., "The innate immune response to bacterial flagellin is mediated by Toll-like receptor 5," Nature, vol. 410, no. 6832, pp. 1099-1103, 2001.

[10] D. M. Underhill, A. Aderem, F. Hayashi et al., "The innate immune response to bacterial flagellin is mediated by Toll-like receptor 5," Nature, vol. 410, no. 6832, pp. 1099-1103, 2001.

[11] J. Faber, C. U. Meyer, C. Gemmer et al., "Human toll-like receptor 4 mutations are associated with susceptibility to invasive meningococcal disease in infancy," The Pediatric Infectious Disease Journal, vol. 25, no. 1, pp. 80-81, 2006.

[12] M. S. Sanders, G. T. J. van Well, S. Ouburg, P. S. J. Lundberg, A. M. Van Furth, and S. A. Morré, "Single nucleotide polymorphisms in TLR9 are highly associated with susceptibility to bacterial meningitis in children," Clinical Infectious Diseases, vol. 52, no. 4, pp. 475-480, 2011.

[13] S. Akira, S. Uematsu, and O. Takeuchi, "Pathogen recognition and innate immunity," Cell, vol. 124, no. 4, pp. 783-801, 2006.

[14] T.-D. Kanneganti, M. Lamkanfi, and G. Núñez, "Intracellular NOD-like receptors in host defense and disease," Immunity, vol. 27, no. 4, pp. 549-559, 2007.

[15] A. Denes, G. Lopez-Castejon, and D. Brough, "Caspase-1: is IL-1 just the tip of the ICEberg?" Cell Death and Disease, vol. 3, no. 7, article e338, 2012.

[16] A. W. Segal, "How neutrophils kill microbes," Annual Review of Immunology, vol. 23, pp. 197-223, 2005.

[17] J. C. Sun, S. Ugolini, and E. Vivier, "Immunological memory within the innate immune system," The EMBO Journal, vol. 33, no. 12, pp. 1295-1303, 33.

[18] A. Kolb-Mäurer, A. Unkmeir, U. Kämmerer et al., "Interaction of Neisseria meningitidis with human dendritic cells," Infection and Immunity, vol. 69, no. 11, pp. 6912-6922, 2001.

[19] S. M. Zughaier, "Neisseria meningitidis capsular polysaccharides induce inflammatory responses via TLR2 and TLR4-MD2," Journal of Leukocyte Biology, vol. 89, no. 3, pp. 469-480, 2011.

[20] C. L. Sokol, G. M. Barton, A. G. Farr, and R. Medzhitov, "A mechanism for the initiation of allergen-induced $T$ helper type 2 responses," Nature Immunology, vol. 9, no. 3, pp. 310-318, 2008.

[21] M. Merad, P. Sathe, J. Helft, J. Miller, and A. Mortha, "The dendritic cell lineage: ontogeny and function of dendritic cells and their subsets in the steady state and the inflamed setting," Annual Review of Immunology, vol. 31, pp. 563-604, 2013.

[22] C. A. Janeway, P. Travers, M. Walport et al., Immunobiology, Garland Science, New York, NY, USA, 2001. 
[23] M. Pizza and R. Rappuoli, "Neisseria meningitidis: pathogenesis and immunity," Current Opinion in Microbiology, vol. 23, pp. 68-72, 2015.

[24] E. Del Tordello and D. Serruto, "Functional genomics studies of the human pathogen Neisseria meningitidis," Briefings in Functional Genomics, vol. 12, no. 4, pp. 328-340, 2013.

[25] C. Schoen, H. Tettelin, J. Parkhill, and M. Frosch, "Genome flexibility in Neisseria meningitidis," Vaccine, vol. 27, supplement 2, pp. B103-B111, 2009.

[26] P. M. Power and E. R. Moxon, "Phase variation and adaptive strategies of $N$. meningitidis: insights into the biology of a commensal and pathogen," in Handbook of Meningococcal Disease: Infection Biology, Vaccination, Clinical Management, M. Frosch and M. C. J. Maiden, Eds., Wiley-Blackwell, 2006.

[27] E. Rotman and H. S. Seifert, "The genetics of Neisseria species," Annual Review of Genetics, vol. 48, no. 1, pp. 405-431, 2014.

[28] P. R. Marri, M. Paniscus, N. J. Weyand et al., "Genome sequencing reveals widespread virulence gene exchange among human Neisseria species," PLoS ONE, vol. 5, no. 7, Article ID el1835, 2010.

[29] L. A. S. Snyder, S. A. Jarvis, and N. J. Saunders, "Complete and variant forms of the 'gonococcal genetic island' in Neisseria meningitidis," Microbiology, vol. 151, no. 12, pp. 4005-4013, 2005.

[30] B. Joseph, R. F. Schwarz, B. Linke et al., "Virulence evolution of the human pathogen Neisseria meningitidis by recombination in the core and accessory genome," PLoS ONE, vol. 6, no. 4, Article ID e18441, 2011.

[31] L. A. Cahoon and H. S. Seifert, "Focusing homologous recombination: pilin antigenic variation in the pathogenic Neisseria," Molecular Microbiology, vol. 81, no. 5, pp. 1136-1143, 2011.

[32] M. Kawai, I. Uchiyama, and I. Kobayashi, "Genome comparison In Silico in Neisseria suggests integration of filamentous bacteriophages by their own transposase," DNA Research, vol. 12, no. 6, pp. 389-401, 2005.

[33] M. W. J. van Passel, A. van der Ende, and A. Bart, "Plasmid diversity in neisseriae," Infection and Immunity, vol. 74, no. 8, pp. 4892-4899, 2006.

[34] Y. N. Srikhanta, K. L. Fox, and M. P. Jennings, "The phasevarion: phase variation of type III DNA methyltransferases controls coordinated switching in multiple genes," Nature Reviews Microbiology, vol. 8, no. 3, pp. 196-206, 2010.

[35] M. V. R. Weber, H. Claus, M. C. J. Maiden, M. Frosch, and U. Vogel, "Genetic mechanisms for loss of encapsulation in polysialyltransferase-gene-positive meningococci isolated from healthy carriers," International Journal of Medical Microbiology, vol. 296, no. 7, pp. 475-484, 2006.

[36] A. van der Ende, C. T. P. Hopman, and J. Dankert, "Multiple mechanisms of phase variation of PorA in Neisseria meningitidis," Infection and Immunity, vol. 68, no. 12, pp. 6685-6690, 2000.

[37] P. Martin, K. Makepeace, S. A. Hill, D. W. Hood, and E. R. Moxon, "Microsatellite in instability regulates transcription factor binding and gene expression," Proceedings of the National Academy of Sciences of the United States of America, vol. 102, no. 10, pp. 3800-3804, 2005.

[38] R. Tobes and E. Pareja, "Bacterial repetitive extragenic palindromic sequences are DNA targets for Insertion Sequence elements," BMC Genomics, vol. 7, article 62, 2006.

[39] L. Fagnocchi, E. Pigozzi, V. Scarlato, and I. Delany, "In the NadR regulon, adhesins and diverse meningococcal functions are regulated in response to signals in human saliva," Journal of Bacteriology, vol. 194, no. 2, pp. 460-474, 2012.
[40] L. A. S. Snyder, S. A. Butcher, and N. J. Saunders, "Comparative whole-genome analyses reveal over 100 putative phase-variable genes in the pathogenic Neisseria spp.", Microbiology, vol. 147, no. 8, pp. 2321-2332, 2001.

[41] A. Rytkönen, B. Albiger, P. Hansson-Palo et al., "Neisseria meningitidis undergoes PilC phase variation and PilE sequence variation during invasive disease," Journal of Infectious Diseases, vol. 189, no. 3, pp. 402-409, 2004.

[42] P. Martin, L. Sun, D. W. Hood, and E. R. Moxon, "Involvement of genes of genome maintenance in the regulation of phase variation frequencies in Neisseria meningitidis," Microbiology, vol. 150, no. 9, pp. 3001-3012, 2004.

[43] A. R. Richardson and I. Stojiljkovic, "Mismatch repair and the regulation of phase variation in Neisseria meningitidis," Molecular Microbiology, vol. 40, no. 3, pp. 645-655, 2001.

[44] L. A. S. Snyder, N. J. Saunders, and W. M. Shafer, "A putatively phase variable gene $(d c a)$ required for natural competence in Neisseria gonorrhoeae but not Neisseria meningitidis is located within the division cell wall $(d c w)$ gene cluster," Journal of Bacteriology, vol. 183, no. 4, pp. 1233-1241, 2001.

[45] P. van Ulsen, B. Adler, P. Fassler et al., "A novel phasevariable autotransporter serine protease, AusI, of Neisseria meningitidis," Microbes and Infection, vol. 8, no. 8, pp. 20882097, 2006.

[46] N. J. Oldfield, S. Matar, F. A. Bidmos et al., "Prevalence and phase variable expression status of two autotransporters, $\mathrm{NalP}$ and MspA, in carriage and disease isolates of Neisseria meningitides," PLoS ONE, vol. 8, no. 7, Article ID e69746, 2013.

[47] M. J. Warren and M. P. Jennings, "Identification and characterization of $p p t A$ : a gene involved in the phase-variable expression of phosphorylcholine on pili of Neisseria meningitidis," Infection and Immunity, vol. 71, no. 12, pp. 6892-6898, 2003.

[48] T. Davidsen, M. Bjørås, E. C. Seeberg, and T. Tønjum, "Antimutator role of DNA glycosylase MutY in pathogenic Neisseria species," Journal of Bacteriology, vol. 187, no. 8, pp. 2801-2809, 2005.

[49] N. J. Saunders, A. C. Jeffries, J. F. Peden et al., "Repeat-associated phase variable genes in the complete genome sequence of Neisseria meningitidis strain MC58," Molecular Microbiology, vol. 37, no. 1, pp. 207-215, 2000.

[50] M. M. E. Metruccio, E. Pigozzi, D. Roncarati et al., "A novel phase variation mechanism in the meningococcus driven by a ligand-responsive repressor and differential spacing of distal promoter elements," PLoS Pathogens, vol. 5, no. 12, Article ID e1000710, 2009.

[51] H. L. Alexander, A. W. Rasmussen, and I. Stojiljkovic, "Identification of Neisseria meningitidis genetic loci involved in the modulation of phase variation frequencies," Infection and Immunity, vol. 72, no. 11, pp. 6743-6747, 2004.

[52] A. Siddique, N. Buisine, and R. Chalmers, "The transposonlike correia elements encode numerous strong promoters and provide a potential new mechanism for phase variation in the meningococcus," PLoS Genetics, vol. 7, no. 1, Article ID e1001277, 2011.

[53] M. Mazzone, E. De Gregorio, A. Lavitola, C. Pagliarulo, P. Alifano, and P. P. Di Nocera, "Whole-genome organization and functional properties of miniature DNA insertion sequences conserved in pathogenic Neisseriae," Gene, vol. 278, no. 1-2, pp. 211-222, 2001.

[54] E. de Gregorio, C. Abrescia, M. S. Carlomagno, and P. P. di Nocera, "Asymmetrical distribution of Neisseria miniature 
insertion sequence DNA repeats among pathogenic and nonpathogenic Neisseria strains," Infection and Immunity, vol. 71, no. 7, pp. 4217-4221, 2003.

[55] R. Hilse, S. Hammerschmidt, W. Bautsch, and M. Frosch, "Site-specific insertion of IS1301 and distribution in Neisseria meningitidis strains," Journal of Bacteriology, vol. 178, no. 9, pp. 2527-2532, 1996.

[56] E. Kugelberg, B. Gollan, C. Farrance et al., "The influence of IS 1301 in the capsule biosynthesis locus on meningococcal carriage and disease," PLoS ONE, vol. 5, no. 2, Article ID e9413, 2010.

[57] J. Kiss, Z. Nagy, G. Tóth et al., "Transposition and target specificity of the typical IS30 family element IS1655 from Neisseria meningitidis," Molecular Microbiology, vol. 63, no. 6, pp. 1731-1747, 2007.

[58] H. Tettelin, N. J. Saunders, J. Heidelberg et al., "Complete genome sequence of Neisseria meningitidis serogroup B strain MC58," Science, vol. 287, no. 5459, pp. 1809-1815, 2000.

[59] M. Alamro, F. A. Bidmos, H. Chan et al., "Phase variation mediates reductions in expression of surface proteins during persistent meningococcal carriage," Infection and Immunity, vol. 82, no. 6, pp. 2472-2484, 2014.

[60] M. P. Jennings, Y. N. Srikhanta, E. R. Moxon et al., “The genetic basis of the phase variation repertoire of lipopolysaccharide immunotypes in Neisseria meningitidis," Microbiology, vol. 145, no. 11, pp. 3013-3021, 1999.

[61] P. M. Power, L. F. Roddam, M. Dieckelmann et al., "Genetic characterization of pilin glycosylation in Neisseria meningitidis," Microbiology, vol. 146, no. 4, pp. 967-979, 2000.

[62] P. M. Power, L. F. Roddam, K. Rutter, S. Z. Fitzpatrick, Y. N. Srikhanta, and M. P. Jennings, "Genetic characterization of pilin glycosylation and phase variation in Neisseria meningitidis," Molecular Microbiology, vol. 49, no. 3, pp. 833-847, 2003.

[63] M. M. Estabrook, N. C. Christopher, J. M. Griffiss, C. J. Baker, and R. E. Mandrell, "Sialylation and human neutrophil killing of group C Neisseria meningitidis," The Journal of Infectious Diseases, vol. 166, no. 5, pp. 1079-1088, 1992.

[64] Q. Zhang, Y. Li, and C. M. Tang, "The role of the exopolyphosphatase PPX in avoidance by Neisseria meningitidis of complement-mediated killing," The Journal of Biological Chemistry, vol. 285, no. 44, pp. 34259-34268, 2010.

[65] H. Claus, R. Borrow, M. Achtman et al., "Genetics of capsule O-acetylation in serogroup C, W-135 and Y meningococci," Molecular Microbiology, vol. 51, no. 1, pp. 227-239, 2004.

[66] P. C. Fusco, E. K. Farley, C.-H. Huang, S. Moore, and F. Michon, "Protective meningococcal capsular polysaccharide epitopes and the role of $\mathrm{O}$ acetylation," Clinical and Vaccine Immunology, vol. 14, no. 5, pp. 577-584, 2007.

[67] A. Batista-Duharte, B. Téllez, M. Tamayo et al., "In Silico identification of molecular mimicry between T-cell epitopes of Neisseria meningitidis B and the human proteome," Revista Peruana de Medicina Experimental y Salud Publica, vol. 30, no. 3, pp. 441-445, 2013.

[68] J. Finne, U. Finne, H. Deagostini-Bazin, and C. Goridis, "Occurrence of $\alpha 2-8$ linked polysialosyl units in a neural cell adhesion molecule," Biochemical and Biophysical Research Communications, vol. 112, no. 2, pp. 482-487, 1983.

[69] G. R. Moe and D. M. Granoff, "Molecular mimetics of Neisseria meningitidis serogroup B polysaccharide," International Reviews of Immunology, vol. 20, no. 2, pp. 201-220, 2001.
[70] R. E. Mandrell and M. A. Apicella, "Lipo-oligosaccharides (LOS) of mucosal pathogens: molecular mimicry and hostmodification of LOS," Immunobiology, vol. 187, no. 3-5, pp. 382402, 1993.

[71] A. P. Moran, M. M. Prendergast, and B. J. Appelmelk, "Molecular mimicry of host structures by bacterial lipopolysaccharides and its contribution to disease," FEMS Immunology and Medical Microbiology, vol. 16, no. 2, pp. 105-115, 1996.

[72] H. A. Harvey, W. E. Swords, and M. A. Apicella, "The mimicry of human glycolipids and glycosphingolipids by the lipooligosaccharides of pathogenic Neisseria and Haemophilus," Journal of Autoimmunity, vol. 16, no. 3, pp. 257-262, 2001.

[73] C. M. Tsai, "Molecular mimicry of host structures by lipooligosaccharides of Neisseria meningitidis: characterization of sialylated and nonsialylated lacto-N-neotetraose (Galbetal4GlcNAcbetal-3Galbetal-4Glc) structures in lipooligosaccharides using monoclonal antibodies and specific lectins," Advances in Experimental Medicine and Biology, vol. 491, pp. 525-542, 2001.

[74] H.-C. Wang, T.-P. Ko, M.-L. Wu, S.-C. Ku, H.-J. Wu, and A. H.J. Wang, "Neisseria conserved protein DMP19 is a DNA mimic protein that prevents DNA binding to a hypothetical nitrogenresponse transcription factor," Nucleic Acids Research, vol. 40, no. 12, pp. 5718-5730, 2012.

[75] M. Coureuil, G. Mikaty, F. Miller et al., "Meningococcal type IV pili recruit the polarity complex to cross the brain endothelium," Science, vol. 325, no. 5936, pp. 83-87, 2009.

[76] F. Miller, G. Phan, T. Brissac et al., "The hypervariable region of meningococcal major pilin PilE controls the host cell response via antigenic variation," mBio, vol. 5, no. 1, Article ID e01024-13, 2013.

[77] M. P. Bos, B. Tefsen, P. Voet, V. Weynants, J. P. M. Van Putten, and J. Tommassen, "Function of neisserial outer membrane phospholipase A in autolysis and assessment of its vaccine potential," Infection and Immunity, vol. 73, no. 4, pp. 2222-2231, 2005.

[78] I. W. Devoe and J. E. Gilchrist, "Release of endotoxin in the form of cell wall blebs during in vitro growth of Neisseria meningitidis," Journal of Experimental Medicine, vol. 138, no. 5, pp. 1156-1167, 1973.

[79] J. S. Swartley, A. A. Marfin, S. Edupuganti et al., "Capsule switching of Neisseria meningitidis," Proceedings of the National Academy of Sciences of the United States of America, vol. 94, no. 1, pp. 271-276, 1997.

[80] T. M. P. P. Castiñeiras, D. E. Barroso, J. W. Marsh et al., "Capsular switching in invasive Neisseria meningitidis, Brazil," Emerging Infectious Diseases, vol. 18, no. 8, pp. 1336-1338, 2012.

[81] P. Stefanelli, C. Fazio, A. Neri, T. Sofia, and P. Mastrantonio, "First report of capsule replacement among electrophoretic type 37 Neisseria meningitidis strains in Italy," Journal of Clinical Microbiology, vol. 41, no. 12, pp. 5783-5786, 2003.

[82] R. S. W. Tsang, D. K. S. Law, S. D. Tyler, G. S. Stephens, M. Bigham, and W. D. Zollinger, "Potential capsule switching from serogroup Y to B: the characterization of three such Neisseria meningitidis isolates causing invasive meningococcal disease in Canada," Canadian Journal of Infectious Diseases and Medical Microbiology, vol. 16, no. 3, pp. 171-174, 2005.

[83] L. M. Hollanda, G. C. G. Cury, R. F. C. Pereira et al., "Effect of mesoporous silica under Neisseria meningitidis transformation process: environmental effects under meningococci transformation," Journal of Nanobiotechnology, vol. 9, article 28, 2011. 
[84] I. B. Mattos, D. A. Alves, L. M. Hollanda, H. J. Ceragiogli, V. Baranauskas, and M. Lancellotti, "Effects of multi-walled carbon nanotubes (MWCNT) under Neisseria meningitidis transformation process," Journal of Nanobiotechnology, vol. 9, article 53, 2011.

[85] U. Vogel, M.-K. Taha, J. A. Vazquez et al., "Predicted strain coverage of a meningococcal multicomponent vaccine (4CMenB) in Europe: a qualitative and quantitative assessment," The Lancet Infectious Diseases, vol. 13, no. 5, pp. 416-425, 2013.

[86] A. J. Beddek, M.-S. Li, J. S. Kroll, T. W. Jordan, and D. R. Martin, "Evidence for capsule switching between carried and diseasecausing Neisseria meningitidis strains," Infection and Immunity, vol. 77, no. 7, pp. 2989-2994, 2009.

[87] L. H. Harrison, K. A. Shutt, S. E. Schmink et al., "Population structure and capsular switching of invasive Neisseria meningitidis isolates in the pre-meningococcal conjugate vaccine eraUnited States, 2000-2005," Journal of Infectious Diseases, vol. 201, no. 8, pp. 1208-1224, 2010.

[88] P. van der Ley, L. Steeghs, H. J. Hamstra, J. Ten Hove, B. Zomer, and L. Van Alphen, "Modification of lipid a biosynthesis in Neisseria meningitidis lpxL mutants: influence on lipopolysaccharide structure, toxicity, and adjuvant activity," Infection and Immunity, vol. 69, no. 10, pp. 5981-5990, 2001.

[89] J. C. Dunning Hotopp, R. Grifantini, N. Kumar et al., "Comparative genomics of Neisseria meningitidis: core genome, islands of horizontal transfer and pathogen-specific genes," Microbiology, vol. 152, no. 12, pp. 3733-3749, 2006.

[90] H. Lo, C. M. Tang, and R. M. Exley, "Mechanisms of avoidance of host immunity by Neisseria meningitidis and its effect on vaccine development," The Lancet Infectious Diseases, vol. 9, no. 7, pp. 418-427, 2009.

[91] M. C. Schneider, B. E. Prosser, J. J. E. Caesar et al., "Neisseria meningitidis recruits factor $\mathrm{H}$ using protein mimicry of host carbohydrates," Nature, vol. 458, no. 7240, pp. 890-893, 2009.

[92] M. Lappann, S. Danhof, F. Guenther, S. Olivares-Florez, I. L. Mordhorst, and U. Vogel, "In vitro resistance mechanisms of Neisseria meningitidis against neutrophil extracellular traps," Molecular Microbiology, vol. 89, no. 3, pp. 433-449, 2013.

[93] M. Stork, J. Grijpstra, M. P. Bos et al., "Zinc piracy as a mechanism of Neisseria meningitidis for evasion of nutritional immunity," PLoS Pathogens, vol. 9, no. 10, Article ID e1003733, 2013.

[94] M. Saleem, S. M. Prince, S. E. J. Rigby et al., "Use of a molecular decoy to segregate transport from antigenicity in the FrpB iron transporter from Neisseria meningitides," PLoS ONE, vol. 8, no. 2, Article ID e56746, 2013.

[95] K. Hubert, M.-C. Pawlik, H. Claus, H. Jarva, S. Meri, and U. Vogel, "Opc expression, LPS immunotype switch and pilin conversion contribute to serum resistance of unencapsulated meningococci," PLoS ONE, vol. 7, no. 9, Article ID e45132, 2012.

[96] C. M. Tsai, R. Boykins, and C. E. Frasch, "Heterogeneity and variation among Neisseria meningitidis lipopolysaccharides," Journal of Bacteriology, vol. 155, no. 2, pp. 498-504, 1983.

[97] J. Chamot-Rooke, G. Mikaty, C. Malosse et al., "Posttranslational modification of pili upon cell contact triggers $N$. meningitidis dissemination," Science, vol. 331, no. 6018, pp. 778782, 2011.

[98] F. E.-C. Jen, C. E. Jones, J. C. Wilson, B. L. Schulz, and M. P. Jennings, "Substrate recognition of a structure motif for phosphorylcholine post-translational modification in Neisseria meningitidis," Biochemical and Biophysical Research Communications, vol. 431, no. 4, pp. 808-814, 2013.
[99] E. Loh, E. Kugelberg, A. Tracy et al., "Temperature triggers immune evasion by Neisseria meningitidis," Nature, vol. 502, no. 7470, pp. 237-240, 2013.

[100] M. F. Anjum, T. M. Stevanin, R. C. Read, and J. W. B. Moir, "Nitric oxide metabolism in Neisseria meningitidis," Journal of Bacteriology, vol. 184, no. 11, pp. 2987-2993, 2002.

[101] P. Stefanelli, G. Colotti, A. Neri et al., "Molecular characterization of nitrite reductase gene (aniA) and gene product in Neisseria meningitidis isolates: is aniA essential for meningococcal survival?" IUBMB Life, vol. 60, no. 9, pp. 629-636, 2008.

[102] H. Echenique-Rivera, A. Muzzi, E. del Tordello et al., "Transcriptome analysis of Neisseria meningitidis in human whole blood and mutagenesis studies identify virulence factors involved in blood survival," PLoS Pathogens, vol. 7, no. 5, Article ID e1002027, 2011.

[103] H. A. Hadi, K. G. Wooldridge, K. Robinson, and D. A. A. Ala'Aldeen, "Identification and characterization of App: an immunogenic autotransporter protein of Neisseria meningitidis," Molecular Microbiology, vol. 41, no. 3, pp. 611-623, 2001.

[104] J. Arenas, S. Cano, R. Nijland et al., "The meningococcal autotransporter AutA is implicated in autoaggregation and biofilm formation," Environmental Microbiology, vol. 17, no. 4, pp. 1321-1337, 2015.

[105] N. H. Chen, R. M. Couñago, K. Y. Djoko et al., "A glutathionedependent detoxification system is required for formaldehyde resistance and optimal survival of neisseria meningitidis in biofilms," Antioxidants and Redox Signaling, vol. 18, no. 7, pp. 743-755, 2013.

[106] R. B. Neil and M. A. Apicella, "Role of HrpA in biofilm formation of Neisseria meningitidis and regulation of the hrpBAS transcripts," Infection and Immunity, vol. 77, no. 6, pp. 22852293, 2009

[107] A. J. Potter, S. P. Kidd, M. P. Jennings, and A. G. McEwan, "Evidence for distinctive mechanisms of S-nitrosoglutathione metabolism by AdhC in two closely related species, Neisseria gonorrhoeae and Neisseria meningitidis," Infection and Immunity, vol. 75, no. 3, pp. 1534-1536, 2007.

[108] K. Yi, A. W. Rasmussen, S. K. Gudlavalleti, D. S. Stephens, and I. Stojiljkovic, "Biofilm formation by Neisseria meningitidis," Infection and Immunity, vol. 72, no. 10, pp. 6132-6138, 2004.

[109] S. Agarwal, S. Vasudhev, R. B. DeOliveira, and S. Ram, "Inhibition of the classical pathway of complement by meningococcal capsular polysaccharides," The Journal of Immunology, vol. 193, no. 4, pp. 1855-1863, 2014.

[110] A. C. Pridmore, D. H. Wyllie, F. Abdillahi et al., "A lipopolysaccharide-deficient mutant of Neisseria meningitidis elicits attenuated cytokine release by human macrophages and signals via toll-like receptor (TLR) 2 but not via $\mathrm{TLR}_{4} / \mathrm{MD} 2$," The Journal of Infectious Diseases, vol. 183, no. 1, pp. 89-96, 2001.

[111] L. M. Willis and C. Whitfield, "KpsC and KpsS are retaining 3-deoxy-D-manno-oct-2- ulosonic acid (Kdo) transferases involved in synthesis of bacterial capsules," Proceedings of the National Academy of Sciences of the United States of America, vol. 110, no. 51, pp. 20753-20758, 2013.

[112] T. R. Sampson and D. S. Weiss, "CRISPR-Cas systems: new players in gene regulation and bacterial physiology," Frontiers in Cellular and Infection Microbiology, vol. 4, p. 37, 2014.

[113] K. M. Esvelt, P. Mali, J. L. Braff, M. Moosburner, S. J. Yaung, and G. M. Church, "Orthogonal Cas9 proteins for RNA-guided gene regulation and editing," Nature Methods, vol. 10, no. 11, pp. 1116-1123, 2013. 
[114] E. Kugelberg, B. Gollan, and C. M. Tang, "Mechanisms in Neisseria meningitidis for resistance against complement-mediated killing," Vaccine, vol. 26, supplement 8, pp. I34-I39, 2008.

[115] A. E. Deghmane, D. Giorgini, M. Larribe, J.-M. Alonso, and M.-K. Taha, "Down-regulation of pili and capsule of Neisseria meningitidis upon contact with epithelial cells is mediated by CrgA regulatory protein," Molecular Microbiology, vol. 43, no. 6, pp. 1555-1564, 2002.

[116] R. Ieva, C. Alaimo, I. Delany, G. Spohn, R. Rappuoli, and V. Scarlato, "CrgA is an inducible LysR-type regulator of Neisseria meningitidis, acting both as a repressor and as an activator of gene transcription," Journal of Bacteriology, vol. 187, no. 10, pp. 3421-3430, 2005.

[117] K. O. Johswich, J. Zhou, D. K. S. Law et al., "Invasive potential of nonencapsulated disease isolates of Neisseria meningitides," Infection and Immunity, vol. 80, no. 7, pp. 2346-2353, 2012.

[118] M. J. Uria, Q. Zhang, Y. Li et al., "A generic mechanism in Neisseria meningitidis for enhanced resistance against bactericidal antibodies," Journal of Experimental Medicine, vol. 205, no. 6, pp. 1423-1434, 2008.

[119] T. M. Stevanin, J. R. Laver, R. K. Poole, J. W. B. Moir, and R. C. Read, "Metabolism of nitric oxide by Neisseria meningitidis modifies release of NO-regulated cytokines and chemokines by human macrophages," Microbes and Infection, vol. 9, no. 8, pp. 981-987, 2007.

[120] T. M. Stevanin, J. W. B. Moir, and R. C. Read, "Nitric oxide detoxification systems enhance survival of Neisseria meningitidis in human macrophages and in nasopharyngeal mucosa," Infection and Immunity, vol. 73, no. 6, pp. 3322-3329, 2005.

[121] T. Davidsen, E. K. Amundsen, E. A. Rødland, and T. Tønjum, "DNA repair profiles of disease-associated isolates of Neisseria meningitidis," FEMS Immunology and Medical Microbiology, vol. 49, no. 2, pp. 243-251, 2007.

[122] A. K. Criss and H. S. Seifert, "A bacterial siren song: intimate interactions between Neisseria and neutrophils," Nature Reviews Microbiology, vol. 10, no. 3, pp. 178-190, 2012.

[123] S. Schielke, C. Spatz, R. F. Schwarz et al., "Characterization of FarR as a highly specialized, growth phase-dependent transcriptional regulator in Neisseria meningitidis," International Journal of Medical Microbiology, vol. 301, no. 4, pp. 325-333, 2011.

[124] J. Kortekaas, S. A. Müller, P. Ringler et al., "Immunogenicity and structural characterisation of an in vitro folded meningococcal siderophore receptor (FrpB, FetA)," Microbes and Infection, vol. 8, no. 8, pp. 2145-2153, 2006.

[125] J. Kortekaas, A. Pettersson, J. van der Biezen et al., "Shielding of immunogenic domains in Neisseria meningitidis FrpB (FetA) by the major variable region," Vaccine, vol. 25, no. 1, pp. 72-84, 2007.

[126] K. O. Mironov, A. E. Platonov, I. S. Koroleva et al., "Monitoring for Neisseria meningitidis species using sequencing of variable fragments of surface proteins FetA and PorA genes," Zhurnal Mikrobiologii, Epidemiologii, i Immunobiologii, no. 3, pp. 23-27, 2009.

[127] J. A. Welsch and S. Ram, "Factor H and Neisserial pathogenesis," Vaccine, vol. 26, no. 8, pp. I40-I45, 2008.

[128] P. van der Ley, J. van der Biezen, R. Sutmuller, P. Hoogerhout, and J. T. Poolman, "Sequence variability of FrpB, a major ironregulated outer-membrane protein in the pathogenic neisseriae," Microbiology, vol. 142, no. 11, pp. 3269-3274, 1996.

[129] I. Delany, R. Rappuoli, and V. Scarlato, "Fur functions as an activator and as a repressor of putative virulence genes in
Neisseria meningitidis," Molecular Microbiology, vol. 52, no. 4, pp. 1081-1090, 2004.

[130] H. Takahashi, K. Hirose, and H. Watanabe, "Necessity of meningococcal $\gamma$-glutamyl aminopeptidase for Neisseria meningitidis growth in rat cerebrospinal fluid (CSF) and CSF-like medium," Journal of Bacteriology, vol. 186, no. 1, pp. 244-247, 2004.

[131] A. W. Rasmussen, H. L. Alexander, D. Perkins-Balding, W. M. Shafer, and I. Stojiljkovic, "Resistance of Neisseria meningitidis to the toxic effects of heme iron and other hydrophobic agents requires expression of ght," Journal of Bacteriology, vol. 187, no. 15, pp. 5214-5223, 2005.

[132] F. Putker, A. Grutsch, J. Tommassen, and M. P. Bos, "Ght protein of neisseria meningitidis is involved in the regulation of lipopolysaccharide biosynthesis," Journal of Bacteriology, vol. 196, no. 4, pp. 780-789, 2014.

[133] R. Colicchio, S. Ricci, F. Lamberti et al., "The meningococcal ABC-type L-glutamate transporter GltT is necessary for the development of experimental meningitis in mice," Infection and Immunity, vol. 77, no. 9, pp. 3578-3587, 2009.

[134] A. Talà, C. Monaco, K. Nagorska et al., "Glutamate utilization promotes meningococcal survival in vivo through avoidance of the neutrophil oxidative burst," Molecular Microbiology, vol. 81, no. 5, pp. 1330-1342, 2011.

[135] C. S. Hong, W. Hashimoto, A. M. Fialho, T. K. Das Gupta, and A. M. Chakrabarty, "Disrupting the entry barrier and attacking brain tumors: the role of the Neisseria H.8 epitope and the Laz protein," Cell Cycle, vol. 5, no. 15, pp. 1633-1641, 2006.

[136] W. Baehr, E. C. Gotschlich, and P. J. Hitchcock, "The virulenceassociated gonococcal H.8 gene encodes 14 tandemly repeated pentapeptides," Molecular Microbiology, vol. 3, no. 1, pp. 49-55, 1989.

[137] J. R. Black, W. J. Black, and J. G. Cannon, "Neisserial antigen $\mathrm{H} .8$ is immunogenic in patients with disseminated gonococcal and meningococcal infections," Journal of Infectious Diseases, vol. 151, no. 4, pp. 650-657, 1985.

[138] T. D. Ray, L. A. Lewis, S. Gulati, P. A. Rice, and S. Ram, "Novel blocking human IgG directed against the pentapeptide repeat motifs of Neisseria meningitidis Lip/H.8 and Laz lipoproteins," Journal of Immunology, vol. 186, no. 8, pp. 4881-4894, 2011.

[139] I. Tauseef, O. B. Harrison, K. G. Wooldridge et al., "Influence of the combination and phase variation status of the haemoglobin receptors $\mathrm{HmbR}$ and $\mathrm{HpuAB}$ on meningococcal virulence," Microbiology, vol. 157, no. 5, pp. 1446-1456, 2011.

[140] J. Lucidarme, J. Findlow, H. Chan et al., “The distribution and 'in vivo' phase variation status of haemoglobin receptors in invasive meningococcal serogroup B disease: genotypic and phenotypic analysis," PLoS ONE, vol. 8, no. 9, Article ID e76932, 2013.

[141] H. Omer, G. Rose, K. A. Jolley et al., "Genotypic and phenotypic modifications of Neisseria meningitidis after an accidental human passage," PLoS ONE, vol. 6, no. 2, Article ID e17145, 2011.

[142] L. Fantappiè, M. M. E. Metruccio, K. L. Seib et al., "The RNA chaperone Hfq is involved in stress response and virulence in Neisseria meningitidis and is a pleiotropic regulator of protein expression," Infection and Immunity, vol. 77, no. 5, pp. 18421853, 2009.

[143] S. Vitovski, R. C. Read, and J. R. Sayers, "Invasive isolates of Neisseria meningitidis possess enhanced immunoglobulin A1 protease activity compared to colonizing strains," The FASEB Journal, vol. 13, no. 2, pp. 331-337, 1999. 
[144] S. A. Spence, V. L. Clark, and V. M. Isabella, "The role of catalase in gonococcal resistance to peroxynitrite," Microbiology, vol. 158, no. 2, pp. 560-570, 2012.

[145] H.-J. Wu, K. L. Seib, J. L. Edwards, M. A. Apicella, A. G. McEwan, and M. P. Jennings, "Azurin of pathogenic Neisseria spp. is involved in defense against hydrogen peroxide and survival within cervical epithelial cells," Infection and Immunity, vol. 73, no. 12, pp. 8444-8448, 2005.

[146] V. Roussel-Jazédé, I. Jongerius, M. P. Bos, J. Tommassen, and P. Van Ulsen, "NalP-mediated proteolytic release of lactoferrinbinding protein B from the meningococcal cell surface," Infection and Immunity, vol. 78, no. 7, pp. 3083-3089, 2010.

[147] R. Exley, M. Winterbotham, Q. Zhang, V. Pelicic, and C. M. Tang, "A Conserved Major Pilin subunit in Neisseria meningitidis," http://www.meningitis.org/assets/x/52309.

[148] S. A. Brown, K. L. Palmer, and M. Whiteley, "Revisiting the host as a growth medium," Nature Reviews Microbiology, vol. 6, no. 9, pp. 657-666, 2008.

[149] S. Piek, Z. Wang, J. Ganguly et al., "The role of oxidoreductases in determining the function of the neisserial lipid a phosphoethanolamine transferase required for resistance to polymyxin," PLoS ONE, vol. 9, no. 9, Article ID e106513, 2014.

[150] R. S. W. Tsang, D. K. S. Law, C.-M. Tsai, and L.-K. Ng, "Detection of the 1st gene in different serogroups and LOS immunotypes of Neisseria meningitidis," FEMS Microbiology Letters, vol. 199, no. 2, pp. 203-206, 2001.

[151] N. J. Griffiths, D. J. Hill, E. Borodina et al., "Meningococcal surface fibril (Msf) binds to activated vitronectin and inhibits the terminal complement pathway to increase serum resistance," Molecular Microbiology, vol. 82, no. 5, pp. 1129-1149, 2011.

[152] M. K. Bielecka, N. Devos, M. Gilbert et al., "Recombinant protein truncation strategy for inducing bactericidal antibodies to the macrophage infectivity potentiator protein of Neisseria meningitidis and circumventing potential cross-reactivity with human FK506-binding proteins," Infection and Immunity, vol. 83, no. 2, pp. 730-742, 2015.

[153] N. Tsolakos, C. Brookes, S. Taylor et al., "Identification of vaccine antigens using integrated proteomic analyses of surface immunogens from serogroup B Neisseria meningitidis," Journal of Proteomics, vol. 101, pp. 63-76, 2014.

[154] Y.-L. Tzeng, A. Datta, K. Ambrose et al., “The MisR/MisS twocomponent regulatory system influences inner core structure and immunotype of lipooligosaccharide in Neisseria meningitidis," The Journal of Biological Chemistry, vol. 279, no. 33, pp. 35053-35062, 2004.

[155] J. Adu-Bobie, P. Lupetti, B. Brunelli et al., "GNA33 of Neisseria meningitidis is a lipoprotein required for cell separation, membrane architecture, and virulence," Infection and Immunity, vol. 72, no. 4, pp. 1914-1919, 2004.

[156] K. L. Seib, H.-J. Tseng, A. G. McEwan, M. A. Apicella, and M. P. Jennings, "Defenses against oxidative stress in Neisseria gonorrhoeae and Neisseria meningitidis: distinctive systems for different lifestyles," The Journal of Infectious Diseases, vol. 190, no. 1, pp. 136-147, 2004.

[157] M. Antoine, A. Gand, S. Boschi-Muller, and G. Branlant, "Characterization of the amino acids from Neisseria meningitidis MsrA involved in the chemical catalysis of the methionine sulfoxide reduction step," The Journal of Biological Chemistry, vol. 281, no. 51, pp. 39062-39070, 2006.

[158] Y.-L. Tzeng, K. D. Ambrose, S. Zughaier et al., "Cationic antimicrobial peptide resistance in Neisseria meningitidis," Journal of Bacteriology, vol. 187, no. 15, pp. 5387-5396, 2005.
[159] R. M. Delahay, B. D. Robertson, J. T. Balthazar, W. M. Shafer, and C. A. Ison, "Involvement of the gonococcal MtrE protein in the resistance of Neisseria gonorrhoeae to toxic hydrophobic agents," Microbiology, vol. 143, no. 7, pp. 2127-2133, 1997.

[160] M. Comanducci, S. Bambini, B. Brunelli et al., "NadA, a novel vaccine candidate of Neisseria meningitidis," The Journal of Experimental Medicine, vol. 195, no. 11, pp. 1445-1454, 2002.

[161] B. Capecchi, J. Adu-Bobie, F. di Marcello et al., "Neisseria meningitidis NadA is a new invasin which promotes bacterial adhesion to and penetration into human epithelial cells," Molecular Microbiology, vol. 55, no. 3, pp. 687-698, 2005.

[162] C. Mazzon, B. Baldani-Guerra, P. Cecchini et al., "IFN- $\gamma$ and R-848 dependent activation of human monocyte-derived dendritic cells by Neisseria meningitidis adhesin A," The Journal of Immunology, vol. 179, no. 6, pp. 3904-3916, 2007.

[163] G. Bozza, M. Capitani, P. Montanari et al., "Role of ARF6, Rab11 and external Hsp90 in the trafficking and recycling of recombinant-soluble neisseria meningitidis adhesin $\mathrm{A}$ ( $\mathrm{rNadA})$ in human epithelial cells," PLoS ONE, vol. 9, no. 10, Article ID el10047, 2014.

[164] V. Nägele, J. Heesemann, S. Schielke, L. F. Jiménez-Soto, O. Kurzai, and N. Ackermann, "Neisseria meningitidis adhesin NadA targets betal integrins: functional similarity to Yersinia invasion," The Journal of Biological Chemistry, vol. 286, no. 23, pp. 20536-20546, 2011.

[165] S. Franzoso, C. Mazzon, M. Sztukowska et al., "Human monocytes/macrophages are a target of Neisseria meningitidis Adhesin A (NadA)," Journal of Leukocyte Biology, vol. 83, no. 5, pp. 1100-1110, 2008.

[166] P. van Ulsen, L. van Alphen, J. ten Hove, F. Fransen, P. van der Ley, and J. Tommassen, "A Neisserial autotransporter NalP modulating the processing of other autotransporters," Molecular Microbiology, vol. 50, no. 3, pp. 1017-1030, 2003.

[167] S. Bambini, J. Piet, A. Muzzi et al., "An analysis of the sequence variability of meningococcal fHbp, NadA and NHBA over a 50year period in the Netherlands," PLoS ONE, vol. 8, no. 5, Article ID e65043, 2013.

[168] I. R. Peak, Y. N. Srikhanta, V. E. Weynants, C. Feron, J. T. Poolman, and M. P. Jennings, "Evaluation of truncated NhhA protein as a candidate meningococcal vaccine antigen," PLoS ONE, vol. 8, no. 9, Article ID e72003, 2013.

[169] H. Sjölinder and A.-B. Jonsson, "Imaging of disease dynamics during meningococcal sepsis," PLOS ONE, vol. 2, no. 2, article e241, 2007.

[170] K. R. Barth, V. M. Isabella, and V. L. Clark, "Biochemical and genomic analysis of the denitrification pathway within the genus Neisseria," Microbiology, vol. 155, no. 12, pp. 4093-4103, 2009.

[171] M. Aspholm, F. E. Aas, O. B. Harrison et al., "Structural alterations in a component of cytochrome c oxidase and molecular evolution of pathogenic Neisseria in humans," PLoS Pathogens, vol. 6, no. 8, Article ID e1001055, pp. 55-56, 2010.

[172] J. R. Laver, T. M. Stevanin, S. L. Messenger et al., "Bacterial nitric oxide detoxification prevents host cell S-nitrosothiol formation: a novel mechanism of bacterial pathogenesis," The FASEB Journal, vol. 24, no. 1, pp. 286-295, 2010.

[173] S. Chandra, D. Singh, and T. R. Singh, "Prediction and characterization of T-cell epitopes for epitope vaccine design from outer membrane protein of Neisseria meningitidis serogroup B," Bioinformation, vol. 5, no. 4, pp. 155-161, 2010.

[174] S. Giuntini, D. M. Vu, and D. M. Granoff, "FH-dependent complement evasion by disease-causing meningococcal strains 
with absent fHbp genes or frameshift mutations," Vaccine, vol. 31, no. 38, pp. 4192-4199, 2013.

[175] L. A. Lewis, D. M. Vu, D. M. Granoff, and S. Ram, "Inhibition of the alternative pathway of nonhuman infant complement by porin B2 contributes to virulence of Neisseria meningitidis in the infant rat model," Infection and Immunity, vol. 82, no. 6, pp. 2574-2584, 2014.

[176] J. D. Rock, M. J. Thomson, R. C. Read, and J. W. B. Moir, "Regulation of denitrification genes in Neisseria meningitidis by nitric oxide and the repressor NsrR," Journal of Bacteriology, vol. 189, no. 3, pp. 1138-1144, 2007.

[177] K. Heurlier, M. J. Thomson, N. Aziz, and J. W. B. Moir, "The nitric oxide (NO)-sensing repressor NsrR of Neisseria meningitidis has a compact regulon of genes involved in $\mathrm{NO}$ synthesis and detoxification," Journal of Bacteriology, vol. 190, no. 7, pp. 2488-2495, 2008.

[178] H. J. Lee, B. Rakić, M. Gilbert, W. W. Wakarchuk, S. G. Withers, and N. C. J. Strynadka, "Structural and kinetic characterizations of the polysialic acid O-acetyltransferase OatWY from Neisseria meningitidis," Journal of Biological Chemistry, vol. 284, no. 36, pp. 24501-24511, 2009.

[179] M. Sadarangani, A. J. Pollard, and S. D. Gray-Owen, "Opa proteins and CEACAMs: pathways of immune engagement for pathogenic Neisseria," FEMS Microbiology Reviews, vol. 35, no. 3, pp. 498-514, 2011.

[180] M. J. Callaghan, C. Buckee, N. D. McCarthy et al., "Opa protein repertoires of disease-causing and carried meningococci," Journal of Clinical Microbiology, vol. 46, no. 9, pp. 3033-3041, 2008.

[181] E. Carbonnelle, D. J. Hill, P. Morand et al., "Meningococcal interactions with the host," Vaccine, vol. 27, supplement 2, pp. B78-B89, 2009.

[182] K. O. Johswich, S. E. McCaw, E. Islam et al., "In vivo adaptation and persistence of Neisseria meningitidis within the nasopharyngeal mucosa," PLoS Pathogens, vol. 9, no. 7, Article ID e1003509, 2013.

[183] H. A. Rowe, N. J. Griffiths, D. J. Hill, and M. Virji, “Co-ordinate action of bacterial adhesins and human carcinoembryonic antigen receptors in enhanced cellular invasion by capsulate serum resistant Neisseria meningitidis," Cellular Microbiology, vol. 9, no. 1, pp. 154-168, 2007.

[184] K. Wolff and A. Stern, "Identification and characterization of specific sequences encoding pathogenicity associated proteins in the genome of commensal Neisseria species," FEMS Microbiology Letters, vol. 125, no. 2-3, pp. 255-263, 1995.

[185] M. M. Eason and X. Fan, "The role and regulation of catalase in respiratory tract opportunistic bacterial pathogens," Microbial Pathogenesis, vol. 74, pp. 50-58, 2014.

[186] R. Ieva, D. Roncarati, M. M. E. Metruccio, K. L. Seib, V. Scarlato, and I. Delany, "OxyR tightly regulates catalase expression in Neisseria meningitidis through both repression and activation mechanisms," Molecular Microbiology, vol. 70, no. 5, pp. 11521165, 2008.

[187] C. Dehio, S. D. Gray-Owen, and T. F. Meyer, "Host cell invasion by pathogenic Neisseriae," Sub-Cellular Biochemistry, vol. 33, pp. 61-96, 2000.

[188] J. P. Dillard and K. T. Hackett, "Mutations affecting peptidoglycan acetylation in Neisseria gonorrhoeae and Neisseria meningitidis," Infection and Immunity, vol. 73, no. 9, pp. 56975705, 2005.

[189] I. Linhartova, M. Basler, J. Ichikawa et al., "Meningococcal adhesion suppresses proapoptotic gene expression and promotes expression of genes supporting early embryonic and cytoprotective signaling of human endothelial cells," FEMS Microbiology Letters, vol. 263, no. 1, pp. 109-118, 2006.

[190] H. Takahashi, T. Yanagisawa, K. S. Kim, S. Yokoyama, and M. Ohnishi, "Meningococcal pilV potentiates Neisseria meningitidis type IV pilus-mediated internalization into human endothelial and epithelial cells," Infection and Immunity, vol. 80, no. 12, pp. 4154-4166, 2012.

[191] S. C. Bernard, N. Simpson, O. Join-Lambert et al., "Pathogenic Neisseria meningitidis utilizes CD147 for vascular colonization," Nature Medicine, vol. 20, no. 7, pp. 725-731, 2014.

[192] S. V. Balasingham, R. F. Collins, R. Assalkhou et al., "Interactions between the lipoprotein PilP and the secretin PilQ in Neisseria meningitidis," Journal of Bacteriology, vol. 189, no. 15, pp. 5716-5727, 2007.

[193] S. K. Dash, M. Sharma, S. Khare, and A. Kumar, "rmpM Gene as a genetic marker for human bacterial meningitis," Cellular and Molecular Biology, vol. 58, no. 1, pp. 26-30, 2012.

[194] A. Hey, M.-S. Li, M. J. Hudson, P. R. Langford, and J. Simon Krolla, "Transcriptional profiling of Neisseria meningitidis interacting with human epithelial cells in a long-term in vitro colonization model," Infection and Immunity, vol. 81, no. 11, pp. 4149-4159, 2013.

[195] R. Grifantini, E. Frigimelica, I. Delany et al., "Characterization of a novel Neisseria meningitidis Fur and iron-regulated operon required for protection from oxidative stress: utility of DNA microarray in the assignment of the biological role of hypothetical genes," Molecular Microbiology, vol. 54, no. 4, pp. 962-979, 2004.

[196] R. Gasparini, D. Amicizia, P. L. Lai, and D. Panatto, "Neisseria meningitidis: pathogenetic mechanisms to overcome the human immune defences," Journal of Preventive Medicine and Hygiene, vol. 53, no. 2, pp. 50-55, 2012.

[197] A. Unkmeir, U. Kämmerer, A. Stade et al., "Lipooligosaccharide and polysaccharide capsule: virulence factors of Neisseria meningitidis that determine meningococcal interaction with human dendritic cells," Infection and Immunity, vol. 70, no. 5, pp. 2454-2462, 2002.

[198] M. R. Spinosa, C. Progida, A. Talà, L. Cogli, P. Alifano, and C. Bucci, "The Neisseria meningitidis capsule is important for intracellular survival in human cells," Infection and Immunity, vol. 75, no. 7, pp. 3594-3603, 2007.

[199] A. Talà, L. Cogli, M. D. Stefano et al., "Serogroup-specific interaction of Neisseria meningitidis capsular polysaccharide with host cell microtubules and effects on tubulin polymerization," Infection and Immunity, vol. 82, no. 1, pp. 265-274, 2014.

[200] D. J. Hill, N. J. Griffiths, E. Borodina, and M. Virji, "Cellular and molecular biology of Neisseria meningitidis colonization and invasive disease," Clinical Science, vol. 118, no. 9, pp. 547-564, 2010.

[201] M. Drogari-Apiranthitou, E. J. Kuijper, N. Dekker, and J. Dankert, "Complement activation and formation of the membrane attack complex on serogroup B Neisseria meningitidis in the presence or absence of serum bactericidal activity," Infection and Immunity, vol. 70, no. 7, pp. 3752-3758, 2002.

[202] S. Ram, F. G. Mackinnon, S. Gulati et al., "The contrasting mechanisms of serum resistance of Neisseria gonorrhoeae and group B Neisseria meningitidis,' Molecular Immunology, vol. 36, no. 13-14, pp. 915-928, 1999.

[203] M. J. Simões, M. Cunha, F. Almeida, C. Furtado, and L. Brum, "Molecular surveillance of Neisseria meningitidis capsular switching in Portugal, 2002-2006," Epidemiology and Infection, vol. 137, no. 2, pp. 161-165, 2009. 
[204] L. Craig, N. Volkmann, A. S. Arvai et al., “Type IV pilus structure by cryo-electron microscopy and crystallography: implications for pilus assembly and functions," Molecular Cell, vol. 23, no. 5, pp. 651-662, 2006.

[205] M. Kirchner and T. F. Meyer, "The PilC adhesin of the Neisseria type IV pilus-binding specificities and new insights into the nature of the host cell receptor," Molecular Microbiology, vol. 56, no. 4, pp. 945-957, 2005.

[206] C. J. Orihuela, J. Mahdavi, J. Thornton et al., "Laminin receptor initiates bacterial contact with the blood brain barrier in experimental meningitis models," Journal of Clinical Investigation, vol. 119, no. 6, pp. 1638-1646, 2009.

[207] J. L. Diaz, M. Virji, and J. E. Heckels, "Structural and antigenic differences between two types of meningococcal pili," FEMS Microbiology Letters, vol. 21, no. 2, pp. 181-184, 1984.

[208] R. A. Helm and H. S. Seifert, "Frequency and rate of pilin antigenic variation of Neisseria meningitidis," Journal of Bacteriology, vol. 192, no. 14, pp. 3822-3823, 2010.

[209] M. E. Wörmann, C. L. Horien, J. S. Bennett et al., "Sequence, distribution and chromosomal context of class I and class II pilin genes of Neisseria meningitidis identified in whole genome sequences," BMC Genomics, vol. 15, no. 1, article 253, 2014.

[210] E. Carbonnelle, S. Helaine, X. Nassif, and V. Pelicic, "A systematic genetic analysis in Neisseria meningitidis defines the Pil proteins required for assembly, functionality, stabilization and export of type IV pili," Molecular Microbiology, vol. 61, no. 6, pp. 1510-1522, 2006.

[211] M. Kirchner, D. Heuer, and T. F. Meyer, "CD46-independent binding of neisserial type IV pili and the major pilus adhesin, PilC, to human epithelial cells," Infection and Immunity, vol. 73, no. 5, pp. 3072-3082, 2005.

[212] M. Coureuil, H. Lécuyer, M. G. H. Scott et al., "Meningococcus hijacks a $\beta 2$-adrenoceptor/ $\beta$-arrestin pathway to cross brain microvasculature endothelium," Cell, vol. 143, no. 7, pp. 11491160, 2010.

[213] T. Brissac, G. Mikaty, G. Duménil, M. Coureuil, and X. Nassif, "The meningococcal minor pilin PilX is responsible for type IV pilus conformational changes associated with signaling to endothelial cells," Infection and Immunity, vol. 80, no. 9, pp. 3297-3306, 2012.

[214] M. Virji, S. M. Watt, S. Barker, K. Makepeace, and R. Doyonnas, "The N-domain of the human CD66a adhesion molecule is a target for Opa proteins of Neisseria meningitidis and Neisseria gonorrhoeae," Molecular Microbiology, vol. 22, no. 5, pp. 929939, 1996.

[215] E. R. Watkins, Y. H. Grad, S. Gupta, and C. O. Buckee, "Contrasting within- and between-host immune selection shapes Neisseria Opa repertoires," Scientific Reports, vol. 4, Article ID e6554, 2014.

[216] R. Leuzzi, L. Serino, D. Serruto, and M. Pizza, "Newly described surface structures and adhesion strategies of the pathogenic Neisseriae," in Neisseria: Molecular Mechanisms of Pathogenesis, Caister Academic Press, Norfolk, UK, 2010.

[217] J. Pohlner, R. Halter, and T. F. Meyer, "Neisseria gonorrhoeae IgA protease. Secretion and implications for pathogenesis," Antonie van Leeuwenhoek, vol. 53, no. 6, pp. 479-484, 1987.

[218] D. P. J. Turner, A. G. Marietou, L. Johnston et al., "Characterization of MspA, an immunogenic autotransporter protein that mediates adhesion to epithelial and endothelial cells in Neisseria meningitidis," Infection and Immunity, vol. 74, no. 5, pp. 2957-2964, 2006.
[219] M. Sjölinder, G. Altenbacher, M. Hagner, W. Sun, S. SchedinWeiss, and H. Sjölinder, "Meningococcal outer membrane protein NhhA triggers apoptosis in macrophages," PLoS ONE, vol. 7, no. 1, Article ID e29586, 2012.

[220] V. Nägele, J. Heesemann, S. Schielke, L. F. Jiménez-Soto, O. Kurzai, and N. Ackermann, "Neisseria meningitidis adhesin NadA targets $\beta 1$ integrins: functional similarity to Yersinia invasion," The Journal of Biological Chemistry, vol. 286, no. 23, pp. 20536-20546, 2011.

[221] F. S. Archibald and M. N. Duong, "Superoxide dismutase and oxygen toxicity defenses in the genus Neisseria," Infection and Immunity, vol. 51, no. 2, pp. 631-641, 1986.

[222] S. Sainsbury, J. Ren, J. E. Nettleship, N. J. Saunders, D. I. Stuart, and R. J. Owens, "The structure of a reduced form of OxyR from Neisseria meningitidis," BMC Structural Biology, vol. 10, article 10, 2010.

[223] K. E. Wilks, K. L. R. Dunn, J. L. Farrant et al., "Periplasmic superoxide dismutase in meningococcal pathogenicity," Infection and Immunity, vol. 66, no. 1, pp. 213-217, 1998.

[224] C. Schoen, L. Kischkies, J. Elias, and B. J. Ampattu, "Metabolism and virulence in Neisseria meningitidis," Frontiers in Cellular and Infection Microbiology, vol. 4, p. 114, 2014.

[225] J. A. Gómez, M. T. Criado, and C. M. Ferreirós, "Cooperation between the components of the meningococcal transferrin receptor, $\mathrm{TbpA}$ and $\mathrm{TbpB}$, in the uptake of transferrin iron by the $37-\mathrm{kDa}$ ferric-binding protein ( $\mathrm{FbpA})$," Research in Microbiology, vol. 149, no. 6, pp. 381-387, 1998.

[226] K. L. R. Dunn, J. L. Farrant, P. R. Langford, and J. S. Kroll, "Bacterial $[\mathrm{Cu}, \mathrm{Zn}]$-cofactored superoxide dismutase protects opsonized, encapsulated Neisseria meningitidis from phagocytosis by human monocytes/macrophages," Infection and Immunity, vol. 71, no. 3, pp. 1604-1607, 2003.

[227] R. M. Exley, J. Shaw, E. Mowe et al., "Available carbon source influences the resistance of Neisseria meningitidis against complement," Journal of Experimental Medicine, vol. 201, no. 10, pp. 1637-1645, 2005.

[228] D. Serruto and C. L. Galeotti, “The signal peptide sequence of a lytic transglycosylase of Neisseria meningitidis is involved in regulation of gene expression," Microbiology, vol. 150, no. 5, pp. 1427-1437, 2004.

[229] H. Takahashi, K. S. Kim, and H. Watanabe, "Meningococcal internalization into human endothelial and epithelial cells is triggered by the influx of extracellular L-glutamate via GltT Lglutamate $\mathrm{ABC}$ transporter in neisseria meningitidis," Infection and Immunity, vol. 79, no. 1, pp. 380-382, 2011.

[230] M. K. Pangburn, V. P. Ferreira, and C. Cortes, "Discrimination between host and pathogens by the complement system," Vaccine, vol. 26, no. 8, supplement, pp. I15-I21, 2008.

[231] I. H. Lepow, L. Pillemer, M. D. Schoenberg et al., "The properdin system and immunity. X. Characterization of partially purified human properdin," Journal of Immunology, vol. 83, pp. 428-436, 1959.

[232] N. A. Cunliffe, N. Snowden, E. M. Dunbar, and M. R. Haeney, "Recurrent meningococcal septicaemia and properdin deficiency," Journal of Infection, vol. 31, no. 1, pp. 67-68, 1995.

[233] D. Panatto, D. Amicizia, P. L. Lai, and R. Gasparini, "Neisseria meningitidis B vaccines," Expert Review of Vaccines, vol. 10, no. 9, pp. 1337-1351, 2011.

[234] R. Gasparini, D. Amicizia, A. Domnich, P. L. Lai, and D. Panatto, "Neisseria meningitidis B vaccines: recent advances and possible immunization policies," Expert Review of Vaccines, vol. 13, no. 3, pp. 345-364, 2014. 
[235] D. Panatto, D. Amicizia, P. L. Lai, M. L. Cristina, A. Domnich, and R. Gasparini, "New versus old meningococcal Group B vaccines: how the new ones may benefit infants \& toddlers," Indian Journal of Medical Research, vol. 138, pp. 835-846, 2013.

[236] D. Male, J. Brostoff, D. B. Roth et al., Immunology, Mosby Elsevier, Toronto, Canada, 2006.

[237] A. Gasparoni, L. Ciardelli, A. Avanzini et al., "Age-related changes in intracellular Th1/Th2 cytokine production, immunoproliferative $\mathrm{T}$ lymphocyte response and natural killer cell activity in newborns, children and adults," Biology of the Neonate, vol. 84, no. 4, pp. 297-303, 2003.

[238] C. Härtel, N. Adam, T. Strunk, P. Temming, M. MüllerSteinhardt, and C. Schultz, "Cytokine responses correlate differentially with age in infancy and early childhood," Clinical and Experimental Immunology, vol. 142, no. 3, pp. 446-453, 2005.

[239] B. Morein, G. Blomqvist, and $\mathrm{K}$. Hu, "Immune responsiveness in the neonatal period," Journal of Comparative Pathology, vol. 137, no. 1, pp. S27-S31, 2007.

[240] I. Goldschneider, E. C. Gotschlich, and M. S. Artenstein, "Human immunity to the meningococcus. II. Development of natural immunity," Journal of Experimental Medicine, vol. 129, no. 6, pp. 1327-1348, 1969.

[241] S. Flexner, "The results of the serum treatment in thirteen hundred cases of epidemic meningitis," The Journal of Experimental Medicine, vol. 17, no. 5, pp. 553-576, 1913.

[242] V. Davenport, E. Groves, C. G. Hobbs, N. A. Williams, and R. S. Heyderman, "Regulation of Th-1 T cell-dominated immunity to Neisseria meningitidis within the human mucosa," Cellular Microbiology, vol. 9, no. 4, pp. 1050-1061, 2007.

[243] N. A. Korzhueva, D. I. Rybalko, V. P. Naglenko, and A. P. Zinchenko, "Specific immunological reactivity in generalized forms of meningococcal infection in children," Zhurnal Mikrobiologii Epidemiologii i Immunobiologii, no. 8, pp. 110-114, 1984.

[244] S. Raziuddin, M. E.-H. El-Awad, and N. A. Mir, "Bacterial meningitis: $\mathrm{T}$ cell activation and immunoregulatory $\mathrm{CD} 4^{+} \mathrm{T}$ cell subset alteration," Journal of Allergy and Clinical Immunology, vol. 87, no. 6, pp. 1115-1120, 1991.

[245] A. J. Pollard, R. Galassini, E. M. Rouppe van der Voort et al., "Cellular immune responses to Neisseria meningitidis in children," Infection and Immunity, vol. 67, no. 5, pp. 2452-2463, 1999.

[246] A. C. Cruz, B. S. Figueredo, S. L. Souza, M. C. Rebelo, A. G. Carvalho, and L. G. Milagres, "Antibody and memory CD4 ${ }^{+}$Tcell responses after meningococcal disease," Vaccine, vol. 32, no. 40, pp. 5145-5148, 2014.

[247] V. Davenport, T. Guthrie, J. Findlow, R. Borrow, N. A. Williams, and R. S. Heyderman, "Evidence for naturally acquired T cellmediated mucosal immunity to Neisseria meningitidis," The Journal of Immunology, vol. 171, no. 8, pp. 4263-4270, 2003.

[248] E. C. Gotschlich, T. Y. Liu, and M. S. Artenstein, "Human immunity to the meningococcus. 3. Preparation and immunochemical properties of the group A, group B, and group C meningococcal polysaccharides," The Journal of Experimental Medicine, vol. 129, no. 6, pp. 1349-1365, 1969.

[249] E. C. Gotschlich, I. Goldschneider, and M. S. Artenstein, "Human immunity to the meningococcus. IV. Immunogenicity of group A and group C meningococcal polysaccharides in human volunteers," Journal of Experimental Medicine, vol. 129, no. 6, pp. 1367-1384, 1969.

[250] E. C. Gotschlich, I. Goldschneider, and M. S. Artenstein, "Meningococcal infections 2. Field trial of group C meningococcal polysaccharide vaccine in 1969-70," Bulletin of the World
Health Organization, vol. 45, Article ID 196970, pp. 279-282, 1971.

[251] M. S. Artenstein, "Control of meningococcal meningitis with meningococcal vaccines," Yale Journal of Biology and Medicine, vol. 48, no. 3, pp. 197-200, 1975.

[252] J. F. Brundage, M. A. K. Ryan, B. H. Feighner, and F. J. Erdtmann, "Meningococcal disease among United States military service members in relation to routine uses of vaccines with different serogroup-specific components, 1964-1998," Clinical Infectious Diseases, vol. 35, no. 11, pp. 1376-1381, 2002.

[253] R. Biselli, A. Fattorossi, P. M. Matricardi, R. Nisini, T. Stroffolini, and R. D'Amelio, "Dramatic reduction of meningococcal meningitis among military recruits in Italy after introduction of specific vaccination," Vaccine, vol. 11, no. 5, pp. 578-581, 1993.

[254] World Health Organization, "International travel and health, 'Meningococcal disease," http://www.who.int/ith/diseases/meningococcal/en/.

[255] K. E. Stein, "Thymus-independent and thymus-dependent responses to polysaccharide antigens," Journal of Infectious Diseases, vol. 165, supplement 1, pp. S49-S52, 1992.

[256] J. I. Ward and K. M. Zangwill, "Haemophilus influenzae vaccines," in Vaccines, WB Saunders, Philadelphia, Pa, USA, 1999.

[257] P. J. Baker, "T cell regulation of the antibody response to bacterial polysaccharide antigens: an examination of some general characteristics and their implications," Journal of Infectious Diseases, vol. 165, supplement, pp. S44-S48, 1992.

[258] M. A. Breukels, A. Zandvoort, G. P. J. M. van den Dobbelsteen et al., "Pneumococcal conjugate vaccines overcome splenic dependency of antibody response to pneumococcal polysaccharides," Infection and Immunity, vol. 69, no. 12, pp. 7583-7587, 2001.

[259] C. A. Siegrist, "Vaccine immunology," http://www.who.int/ immunization/documents/Elsevier_Vaccine_immunology.pdf.

[260] European Medicines Agency, "Nimenrix," http://www.ema .europa.eu/docs/en_GB/document_library/EPAR_-_Public_assessment_report/human/002226/WC500127664.pdf.

[261] Centers for Disease Control and Prevention, "Prevention and control of meningococcal disease: recommendations of the advisory committee on immunization practices (ACIP)," Morbidity and Mortality Weekly Report, vol. 62, no. 2, 2013, http://www.cdc.gov/mmwr/pdf/rr/rr6202.pdf.

[262] European Medicines Agency, "Menveo," http://www.ema.europa .eu/docs/en_GB/document_library/EPAR_-_Public_assessment_ report/human/001095/WC500090150.pdf.

[263] D. Serruto, T. Spadafina, L. Ciucchi et al., "Neisseria meningitidis GNA2132, a heparin-binding protein that induces protective immunity in humans," Proceedings of the National Academy of Sciences of the United States of America, vol. 107, no. 8, pp. 37703775, 2010.

[264] J. A. Welsch, G. R. Moe, R. Rossi, J. Adu-Bobie, R. Rappuoli, and D. M. Granoff, "Antibody to genome-derived neisserial antigen 2132, a Neisseria meningitidis candidate vaccine, confers protection against bacteremia in the absence of complementmediated bactericidal activity," The Journal of Infectious Diseases, vol. 188, no. 11, pp. 1730-1740, 2003.

[265] J. S. Plested and D. M. Granoff, "Vaccine-induced opsonophagocytic immunity to Neisseria meningitidis group B," Clinical and Vaccine Immunology, vol. 15, no. 5, pp. 799-804, 2008.

[266] G. Madico, J. A. Welsch, L. A. Lewis et al., "The meningococcal vaccine candidate GNA1870 binds the complement regulatory 
protein factor $\mathrm{H}$ and enhances serum resistance," The Journal of Immunology, vol. 177, no. 1, pp. 501-510, 2006.

[267] M. C. Schneider, R. M. Exley, H. Chan et al., "Functional significance of factor $\mathrm{H}$ binding to Neisseria meningitidis," The Journal of Immunology, vol. 176, no. 12, pp. 7566-7575, 2006.

[268] T. Vesikari, S. Esposito, R. Prymula et al., "Immunogenicity and safety of an investigational multicomponent, recombinant, meningococcal serogroup $B$ vaccine $(4 \mathrm{CMenB})$ administered concomitantly with routine infant and child vaccinations: results of two randomised trials," The Lancet, vol. 381, no. 9869, pp. 825-835, 2013.

[269] D. Toneatto, P. Oster, A. C. W. DeBoer et al., "Early clinical experience with a candidate meningococcal B recombinant vaccine (rMenB) in healthy adults," Human Vaccines, vol. 7, no. 7, pp. 781-791, 2011.

[270] European Medicines Agency, Bexsero, European Medicines Agency, London, UK, 2013, http://www.ema.europa.eu/ema/ index.jsp?curl=pages/medicines/human/medicines/002333/ human_med_001614.jsp\&mid=WC0b01ac058001d124.

[271] Agenzia Italiana del Farmaco, Determina 29 luglio 2013. Classificazione del medicinale per uso umano "Bexsero", ai sensi dell'art 8, comma 10, della legge 24 dicembre 1993, n. 537 (Determina 698/2013). Gazzetta Ufficiale-Serie Generale-no. 194 del 20 agosto 2013.

[272] Food and Drug Administration, “Trumenba," http://www.fda .gov/downloads/BiologicsBloodVaccines/Vaccines/ApprovedProducts/UCM421139.pdf.

[273] L. D. Fletcher, L. Bernfield, V. Barniak et al., "Vaccine Potential of the Neisseria meningitidis 2086 Lipoprotein," Infection and Immunity, vol. 72, no. 4, pp. 2088-2100, 2004.

[274] D. Zhu, Y. Zhang, V. Barniak, L. Bernfield, A. Howell, and G. Zlotnick, "Evaluation of recombinant lipidated P2086 protein as a vaccine candidate for group B Neisseria meningitidis in a murine nasal challenge model," Infection and Immunity, vol. 73, no. 10, pp. 6838-6845, 2005.

[275] D. Zhu, V. Barniak, Y. Zhang, B. Green, and G. Zlotnick, "Intranasal immunization of mice with recombinant lipidated P2086 protein reduces nasal colonization of group B Neisseria meningitidis," Vaccine, vol. 24, no. 26, pp. 5420-5425, 2006.

[276] A. S. Anderson, L. Hao, Q. Jiang et al., "Potential impact of the bivalent rLP2806vaccine on Neisseria meningitidis carriage and invasive serogroup B disease," Human Vaccines and Immunotherapeutics, vol. 9, no. 3, pp. 471-479, 2013.

[277] F. Martinon-Torres, F. Gimenez-Sanchez, E. Bernaola-Iturbe, J. Diez-Domingo, Q. Jiang, and J. L. Perez, "A randomized, phase $1 / 2$ trial of the safety, tolerability, and immunogenicity of bivalent rLP2086 meningococcal B vaccine in healthy infants," Vaccine, vol. 32, no. 40, pp. 5206-5211, 2014.

[278] H. S. Marshall, P. C. Richmond, M. D. Nissen et al., "A phase 2 open-label safety and immunogenicity study of a meningococcal B bivalent rLP2086 vaccine in healthy adults," Vaccine, vol. 31, no. 12, pp. 1569-1575, 2013.

[279] S. L. Harris, D. Zhu, E. Murphy et al., "Preclinical evidence for the potential of a bivalent $\mathrm{fHBP}$ vaccine to prevent Neisseria meningitidis serogroup C disease," Human Vaccines, vol. 7, supplement 1, pp. 68-74, 2011.

[280] M. Konar, D. M. Granoff, and P. T. Beernink, "Importance of inhibition of binding of complement factor $\mathrm{H}$ for serum bactericidal antibody responses to meningococcal factor $\mathrm{H}$ binding protein vaccines," The Journal of Infectious Diseases, vol. 208, no. 4, pp. 627-636, 2013.
[281] L. Lemée, E. Hong, M. Etienne et al., "Genetic diversity and levels of expression of factor $\mathrm{H}$ binding protein among carriage isolates of Neisseria meningitidis," PLoS ONE, vol. 9, no. 9, Article ID e107240, 2014.

[282] M. Delgado, D. Yero, O. Niebla et al., "Lipoprotein NMB0928 from Neisseria meningitidis serogroup B as a novel vaccine candidate," Vaccine, vol. 25, no. 50, pp. 8420-8431, 2007.

[283] C.-A. Hsu, W.-R. Lin, J.-C. Li et al., "Immunoproteomic identification of the hypothetical protein NMB1468 as a novel lipoprotein ubiquitous in Neisseria meningitidis with vaccine potential," Proteomics, vol. 8, no. 10, pp. 2115-2125, 2008.

[284] A. Pettersson, J. Kortekaas, V. E. Weynants et al., "Vaccine potential of the Neisseria meningitidis lactoferrin-binding proteins LbpA and LbpB," Vaccine, vol. 24, no. 17, pp. 3545-3557, 2006.

[285] M.-C. Hung, J. E. Heckels, and M. Christodoulides, "The adhesin complex protein (ACP) of Neisseria meningitidis is a new adhesin with vaccine potential," mBio, vol. 4, no. 2, 2013.

[286] D. Martin, B. R. Brodeur, J. Hamel et al., "Candidate Neisseria meningitidis NspA vaccine," Journal of Biotechnology, vol. 83, no. 1-2, pp. 27-31, 2000.

[287] S. Ying, J. He, M. Yu et al., "Recombinant Neisseria surface protein $\mathrm{A}$ is a potential vaccine candidate against Neisseria meningitides serogroup B," Molecular Medicine Reports, vol. 10, no. 3, pp. 1619-1625, 2014.

[288] F. Haghi, S. N. Peerayeh, S. D. Siadat, and H. Zeighami, "Recombinant outer membrane secretin $\mathrm{PilQ}_{406-770}$ as a vaccine candidate for serogroup B Neisseria meningitidis," Vaccine, vol. 30, no. 9, pp. 1710-1714, 2012.

[289] S. K. Gupta, S. Smita, A. N. Sarangi, M. Srivastava, B. A. Akhoon, and Q. Rahman, "In silico $\mathrm{CD} 4^{+} \mathrm{T}$-cell epitope prediction and HLA distribution analysis for the potential proteins of Neisseria meningitidis Serogroup B-A clue for vaccine development," Vaccine, vol. 28, no. 43, pp. 7092-7097, 2010.

[290] T. Fiebig, F. Berti, F. Freiberger et al., "Functional expression of the capsule polymerase of Neisseria meningitidis serogroup X: a new perspective for vaccine development," Glycobiology, vol. 24, no. 2, pp. 150-158, 2014.

[291] J. Holst, P. Oster, R. Arnold et al., "Vaccines against meningococcal serogroup B disease containing outer membrane vesicles (OMV) lessons from past programs and implications for the future," Human Vaccines and Immunotherapeutics, vol. 9, no. 6, pp. 1241-1253, 2013.

[292] J. Newcombe, T. A. Mendum, C.-P. Ren, and J. McFadden, "Identification of the immunoproteome of the meningococcus by cell surface immunoprecipitation and MS," Microbiology, vol. 160, no. 2, pp. 429-438, 2014.

[293] E. Altindis, R. Cozzi, B. Di Palo et al., "Protectome analysis: a new selective bioinformatics tool for bacterial vaccine candidate discovery," Molecular \& Cellular Proteomics, vol. 14, no. 2, pp. 418-429, 2015.

[294] M. Christodoulides, "Neisseria proteomics for antigen discovery and vaccine development," Expert Review of Proteomics, vol. 11, no. 5, pp. 573-591, 2014.

[295] N. E. Rosenstein, B. A. Perkins, D. S. Stephens et al., "The changing epidemiology of meningococcal disease in the United States, 1992-1996," The Journal of Infectious Diseases, vol. 180, no. 6, pp. 1894-1901, 1999.

[296] E. Miller, D. Salisbury, and M. Ramsay, "Planning, registration, and implementation of an immunisation campaign against meningococcal serogroup C disease in the UK: a success story," Vaccine, vol. 20, supplement 1, pp. S58-S67, 2001. 
[297] R. Gasparini and D. Panatto, "Meningococcal glycoconjugate vaccines," Human Vaccines, vol. 7, no. 2, pp. 170-182, 2011.

[298] F. M. La Force, K. Konde, S. Viviani, and M.-P. Préziosi, “The meningitis vaccine project," Vaccine, vol. 25, supplement 1, pp. 97-100, 2007.

[299] F. Micoli, M. R. Romano, M. Tontini et al., "Development of a glycoconjugate vaccine to prevent meningitis in Africa caused by meningococcal serogroup X," Proceedings of the National Academy of Sciences of the United States of America, vol. 110, no. 47, pp. 19077-19082, 2013.

[300] R. Rappuoli, "The challenge of developing universal vaccines," F1000 Medicine Reports, vol. 3, article 16, 2011.

[301] C. L. Trotter, N. J. Gay, and W. J. Edmunds, "Dynamic models of meningococcal carriage, disease, and the impact of serogroup $\mathrm{C}$ conjugate vaccination," American Journal of Epidemiology, vol. 162, no. 1, pp. 89-100, 2005.

[302] H. Campbell, R. Borrow, D. Salisbury, and E. Miller, "Meningococcal C conjugate vaccine: the experience in England and Wales," Vaccine, vol. 27, supplement 2, pp. B20-B29, 2009.

[303] R. Gasparini, M. Comanducci, D. Amicizia et al., "Molecular and serological diversity of Neisseria meningitidis carrier strains isolated from Italian students aged 14 to 22 years," Journal of Clinical Microbiology, vol. 52, no. 6, pp. 1901-1910, 2014.

[304] Public Health Agency of Canada, Neisseria SPP, Public Health Agency of Canada, Ottawa, Canada, 2011, http://www.phac-aspc .gc.ca/lab-bio/res/psds-ftss/neisseria-eng.php. 


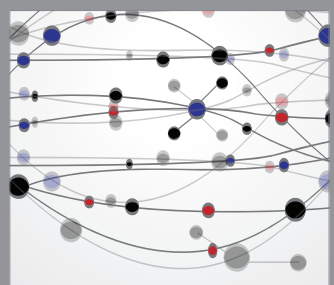

The Scientific World Journal
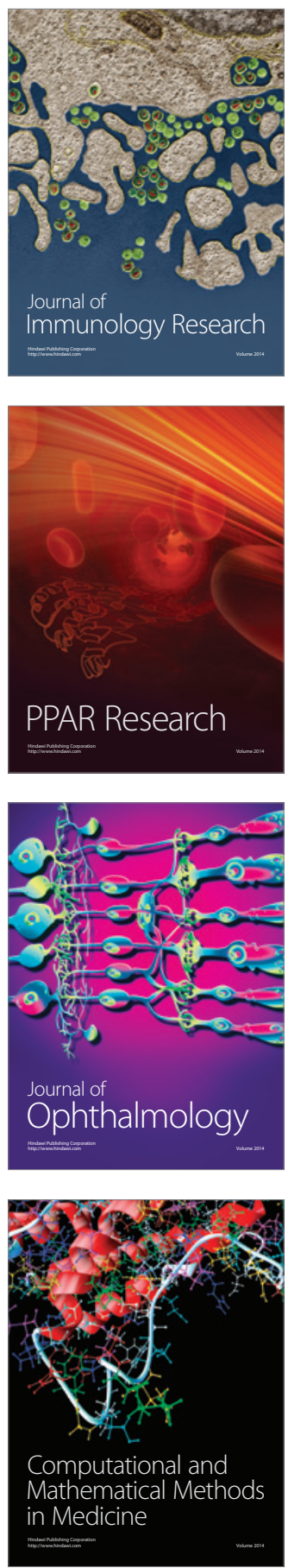

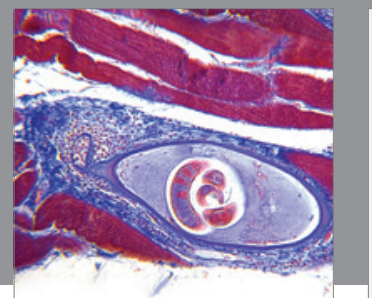

Gastroenterology

Research and Practice
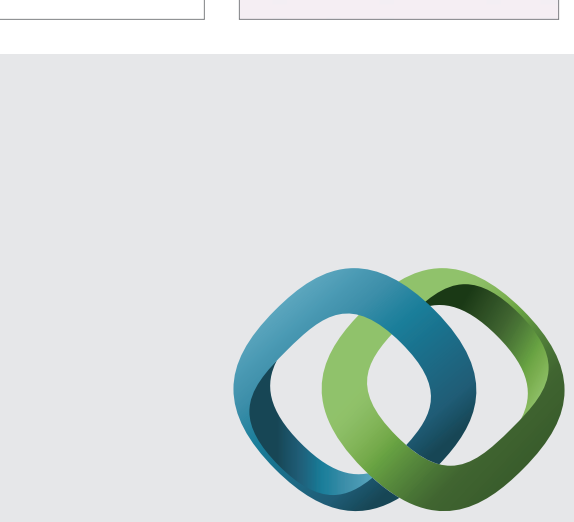

\section{Hindawi}

Submit your manuscripts at

http://www.hindawi.com
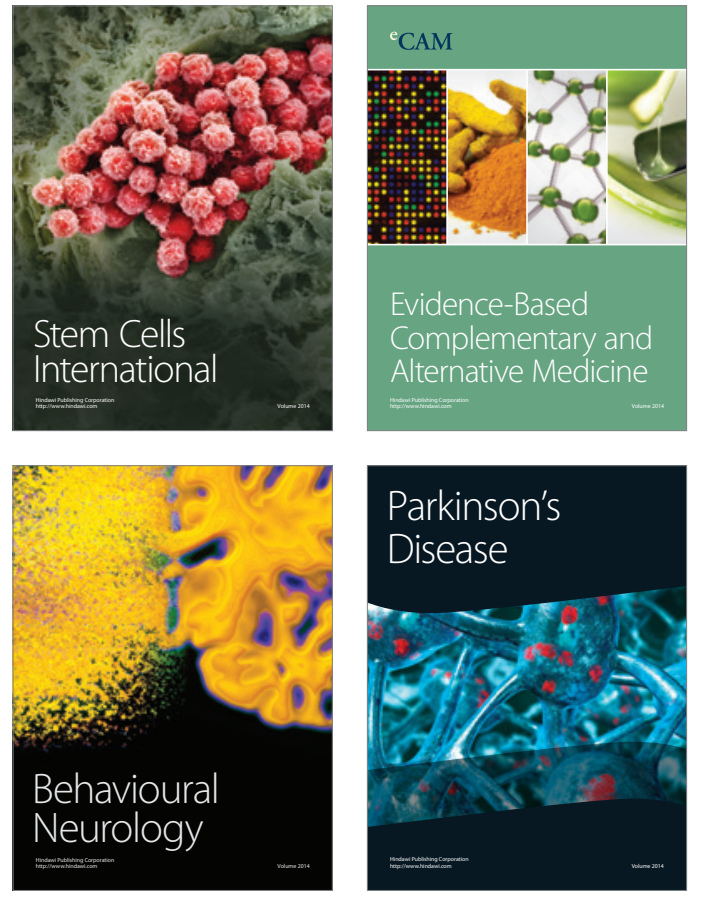
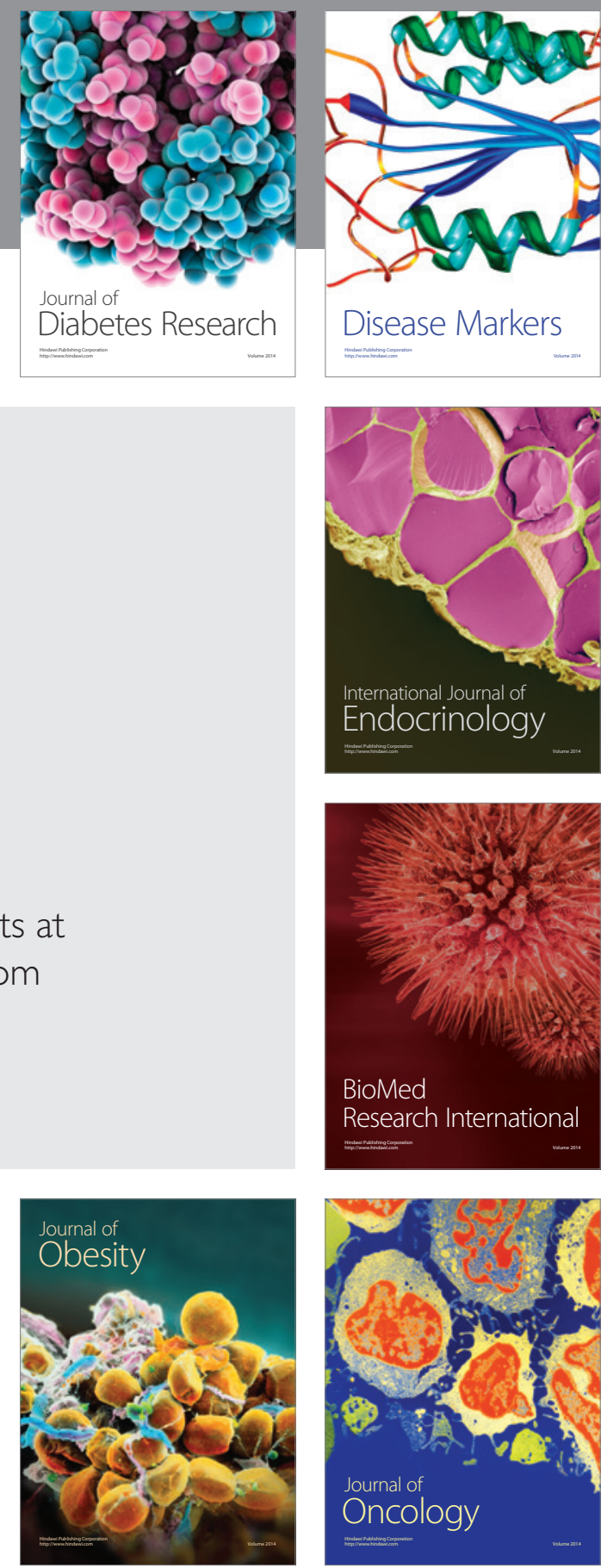

Disease Markers
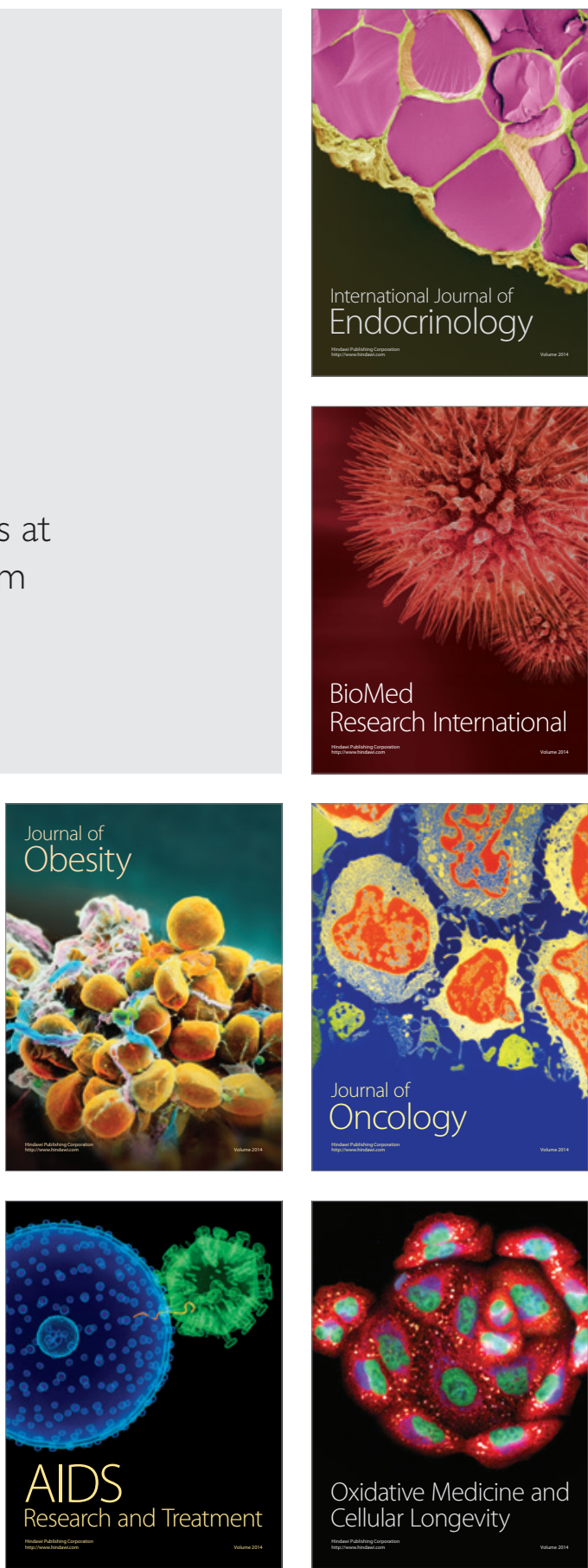